\title{
ŞANLIURFA İLININ TARIMSAL YAPISI, SORUNLARI ve ÇÖZÜM ÖNERILERİ \\ Agricultural Structure, Problems Of Province Of Şanlıurfa And Recommendations
}

\author{
Sedat BENEK \\ Harran Üniversitesi, Fen-Edebiyat Fakültesi, Coğrafya Bölümü, 63100, Şanlıurfa. \\ sbenek@harran.edu.tr
}

\begin{abstract}
Özet: Şanlıurfa ili, genel arazi bölünüşü içerisinde tarım alanları bakımından hem Türkiye'deki tarım alanlarına (\% 36), hem de GAP Bölgesi'ndeki tarım alanlarına (\% 43) göre daha avantajlı bir orana $(\%$ 64,1) sahiptir. Bu bakımdan il, mevcut tarım potansiyeli itibariyle zengin ve elverişli bir durum arz etmektedir. Ancak, modern tarım açısından ele alındı̆̆ında, bu zengin tarım potansiyelinin yeterince değerlendirilmemesinin bir sonucu olarak, çok ciddi temel yapısal sorunlarının bulunduğu dikkat çekmektedir. Bu makalede, GAP çerçevesinde Şanlıurfa ilinin tarımsal yapısının temel sorunlarının başında gelen tarım alanlarının yapısal özellikleri ve coğrafi dă̆llışı, sulama durumu, tarımsal işletme yapısı, arazi toplulaştırma ve tesviyesi, makineleşme, kaliteli tohum kullanımı, gübre ve tarımsal ilaç kullanımı, çiftçi örgütlenmesi, sermaye, ulaşım ve pazarlama konuları incelenmeye çalışılmıştır.
\end{abstract}

Anahtar kelimeler: GAP, Şanlıurfa, Tarımsal Yapı

\begin{abstract}
The province of Şanlurfa has more fertile lands (64.1\%) comparing to the other agricultural lands in Turkey ( $36 \%$ ) and the lands in the GAP Region (43\%, South-East Anatolian Project). Therefore the province is promising a rich and available situation in terms of having agricultural lands. However, when the province is analyzed in terms of using modern agricultural vehicles, as result of lack of not benefiting form the lands enough, it is seen that there are serious structural problems. In this study; the most important issues of the structural features such as agricultural features and geographical dispersion of the lands, irrigation situation, agricultural business structure, mechanization, using quality germs (seeds) using chemical fertilizers and agricultural chemicals, farmer organizations, capital, transportation and marketing are examined.
\end{abstract}

Key Words: GAP, Şanlıurfa, Agricultural Structure

\section{I.Giris}

Araştırma alanımızı oluşturan Şanlıurfa ili, coğrafi bölge ayırımında Güneydoğu Anadolu Bölgesi'nin Orta Fırat Bölümü'nde yer almaktadır. Kapladığı alan itibariyle, Güneydoğu Anadolu Bölgesi'nin en geniş ve Güneydoğu Anadolu Projesi'nin (GAP) merkezi konumunda olan çalışma alanımız, batısında Gaziantep, kuzeybatısında Adıyaman, kuzey ve kuzeydoğusunda Diyarbakır, doğusunda Mardin illeri ve güneyinde ise, $223 \mathrm{~km}$ uzunluğunda Türkiye-Suriye devlet sınırı ile çevrilidir (Şekil 1). Şanlıurfa ilinin idari sınırları fiziki coğrafya açısından incelendiğinde, genel olarak batı ve kuzeybatısı (Fırat nehri), kuzey ve kuzeydoğusu (Karacadağ’ın su bölümü çizgisi) ve doğu (Büyükdere suyu) sınırları doğal, güneydeki Türkiye-Suriye devlet sınırı ${ }^{2}$ ise, siyasi niteliktedir.

Şanlıurfa ili ve çevresi, bulunduğu enlem, bölgeye hakim olan subtropikal hava kütleleri ve rölyefin etkisiyle ülkemizde en kurak şartların yaşandığı alandır. Şanlıurfa ili ve yakın çevresinde görülen bu şiddetli kuraklık, her yerde aynı olmayıp, kuzeyden güneye doğru gidildikçe yükseltinin

\footnotetext{
${ }^{2}$ Türkiye-Suriye devlet sınırı, 1921, 1926, 1929 yıllarında yapılan Ankara Anlaşması ve 1930 Halep protokolüyle çizilmiştir.
} 
azalmasına ve güneyden sokulan subtropikal hava kütlelerinin etkisine bağlı olarak artar. Genel olarak kışları az soğuk, yaz ayları ise çok sıcak geçen çalışma alanımızda, iklim özellikleri tarımsal üretim üzerinde çok büyük bir rol oynamaktadır. Şanlıurfa ilinde ve dolayısıyla Güneydoğu Anadolu Bölgesi'nde birinci derecede tarımsal üretim üzerinde bu kadar olumsuz etki yapan kuraklık durumunu gidermek ve tarım sektörünün temel yapısal sorunlarını ortadan kaldırmak veya en aza indirebilmek için GAP devreye girmiştir.

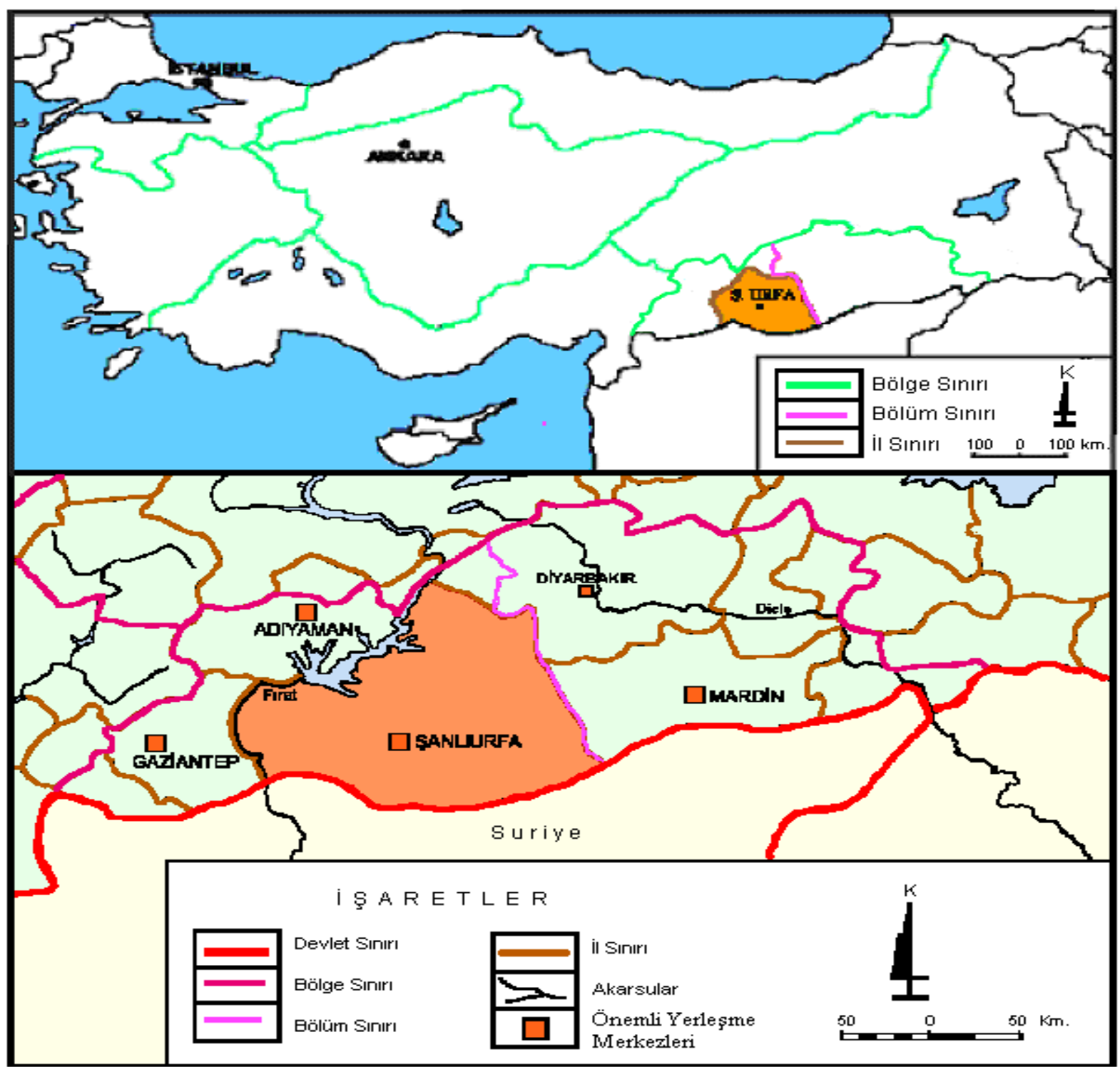

Şekil 1. Şanlıurfa İlinin Türkiye'deki yeri ve konumu

GAP bünyesinde, 17 yıllık (1989-2005) bir dönemi kapsayan süre zarfinda yürütülen çalışmaların, söz konusu projelerin gerek hedeflenen süre içerisinde tamamlanması, gerekse bu yapısal sorunların çözüme kavuşturulması noktasında istenilen düzeye henüz ulaşılamadığı, hatta çok düşük bir seviyede gerçekleştiği görülmektedir. Daha da ötesi, GAP Tarım Master Planı'nda bölgenin tarım ve tarıma dayalı sanayi ile kalkınması öngörülmüş olmasına rağmen, 2005 yılı itibariyle, GAP toplamında tamamlanma oranı \% 52,1 iken, tarım sektörüne yönelik yürütülen projelerin tamamlanma oranı sadece \% 21,1'dir (http://www.gap.gov.tr). Bu durum, GAP çerçevesinde tarım alanındaki 
projelerin gerçekleşme oranının düşük olmasından dolayı, çalışma alanımızda ve dolayısıyla GAP bölgesinde tarımın temel yapısal sorunlarının giderilerek, tarımın modernleşmesini geciktirmektedir.

Bu bağlamda Şanlıurfa ili, mevcut tarım potansiyeli itibariyle zengin ve elverişli bir durum arz etmektedir. Ancak, modern tarım açısından ele alındığında, bu zengin tarım potansiyelinin yeterince değerlendirilmemesinin bir sonucu olarak çok ciddi temel yapısal sorunlarının bulunduğu dikkat çekmektedir. İşte makalenin konusunu, bu temel sorunlarının başında gelen tarım alanlarının yapısal özellikleri ve coğrafi dağıllş̧ı, sulama durumu, tarımsal işletme sayısı, parsel büyüklüğü ve mülkiyet sorunu, arazi toplulaştırma ve tesviyesi, sermaye durumu, çiftçi örgütlenmesi, makineleşme, tohum kullanımı, gübreleme, tarımsal ilaç kullanımı, ulaşım ve pazarlama konuları oluşturmaktadır.

Şanlıurfa ilinde tarımsal ürünler ve bu ürünlerle ilgili faaliyetlerinin ekonomik potansiyeli, gerek GAP ve gerekse Şanlıurfa ili için hammadde sektörünün temelini oluşturmaktadır. Bu nedenle çalışmanın amacı; GAP süreci ile birlikte daha da önem kazanmaya başlayan Şanlıurfa ilinde tarım sektörünün ekstansif tarımdan entansif tarıma geçişte yaşanan sorunlarını belirlemek ve bu sorunlara coğrafi açıdan çözün önerileri sunmaktır. Çalışmanın diğer önemli bir hedefi de, tarımsal ekonomik potansiyelin tespiti sonucunda il ölçüsünde tarım ve tarıma dayalı sanayi sektörü konusundan yapılacak planlamalar için bir temel sağlamaktır. Bu çerçeveden hareketle elde edilen veriler, coğrafya biliminin dağılış, nedensellik, ilişki kurma ve karşılaştırma ilkeleri esas alınarak sentezci bir analizle değerlendirilmiş̧ir. Ayrıca, çalışmanın amacına ve yöntemine uygun olarak metin kısmı çizelge, şekil ve elde edilen sayısal verilerin dağılışını daha iyi gösterebilmek için dağılış ve yoğunluk haritaları hazırlanmış/çizilmiştir.

\section{Tarım Alanlarının Yapısal Özellikleri ve Coğrafi Dağılışı}

Çalışma alanımızda genel arazi bölünüşü içerisinde tarım alanlarının miktarı 1.200.573 (toplam ilin \% 64,1) hektar kadardır. Şanlıurfa ili, genel arazi bölünüşü içerisinde tarım alanları bakımından hem Türkiye'deki tarım alanlarına (\% 36), hem de GAP Bölgesi'ndeki tarım alanlarına (\% $43,6)$ göre daha avantajlı bir orana (\% 64,1) sahiptir. Ayrıca il, bölgedeki toplam tarım alanlarının \% 36,2'sini, Türkiye'deki tarım alanlarının ise \% 4,2'sini oluşturmaktadır (Çizelge 1). Bu büyük potansiyelinden dolayıdır ki Şanlıurfa ili, GAP içerisinde "tarım ve tarıma dayalı ihracat üssü” olarak değerlendirilmektedir.

\begin{tabular}{|c|c|c|c|c|c|c|c|c|}
\hline \multirow{2}{*}{$\begin{array}{c}\text { Arazi } \\
\text { Dağılım }\end{array}$} & \multicolumn{2}{|c|}{ Şanlıurfa İli } & \multicolumn{2}{|c|}{ GAP Bölgesi } & \multicolumn{2}{|c|}{ Türkiye } & \multirow{2}{*}{$\begin{array}{c}\text { Şanlıurfa } \\
\text { İlinin GAP } \\
\text { İçindeki } \\
\text { Payı(\%) }\end{array}$} & \multirow{2}{*}{$\begin{array}{c}\text { Şanlıurfa } \\
\text { İlinin Türkiye } \\
\text { İçindeki } \\
\text { Payı }(\%) \\
\end{array}$} \\
\hline & Alan(da) & $\begin{array}{c}\text { Oran } \\
(\%)\end{array}$ & Alan(da) & $\begin{array}{c}\text { Oran } \\
(\%)\end{array}$ & Alan(da) & $\begin{array}{r}\text { Oran } \\
(\%)\end{array}$ & & \\
\hline Tarım Alanı & 1200573 & 64,1 & 32905750 & 43,6 & 280593970 & 36,0 & 36,2 & 4,2 \\
\hline $\begin{array}{l}\text { Çayır-Mera } \\
\text { Orman- }\end{array}$ & 1579910 & 8,5 & 22144730 & 29,4 & 215060280 & 27,6 & 7,1 & 0,7 \\
\hline $\begin{array}{l}\text { Fundalık } \\
\text { Diğger }\end{array}$ & 156670 & 0,8 & 14511850 & 19,2 & 232482970 & 29,8 & 1,1 & 0,1 \\
\hline $\begin{array}{l}\text { Araziler } \\
\text { Toplam }\end{array}$ & 4931560 & 26,6 & 5847670 & 7,8 & 51314780 & 6,6 & 6,7 & 9,6 \\
\hline Arazi & 18584000 & 100,0 & 75410000 & 100,0 & 779452000 & 100,0 & 84,3 & 2,4 \\
\hline
\end{tabular}

Kaynak: Şanlıurfa Tarım Master Planı, 2002.

Şanlıurfa ilinde genel olarak tarım alanlarının dağılışına bakıldığında, yer şekillerin oluşumuna bağl1 olarak plato yüzeyindeki düzlüklerde ve güneydeki ovalarda kuzeybatı-güneydoğu yönünde uzanan yoğunlukları itibariyle doğu, orta ve batı olmak üzere üç kuşak şeklinde siralanmaktadır (Şekil 2).

Birinci kuşak; Bu kuşak, Fırat nehrinin Hilvan-Siverek ilçeleri arasındaki girintili-çıııntılı alandan başlayarak doğuda, kuzeyden güneye doğru Karacadağ'ın dağlık alanları ile Şanlıurfa-Mardin il sınırı, batıda ise Hilvan, Siverek, Viranşehir ve Ceylanpınar ilçelerinin Şanlıurfa ilçe merkezi ile olan ilçe sınırları arasında uzanan ve güneyde Türkiye-Suriye sınırı ile son bulur (Şekil 2). Bu kuşağın çok büyük bir kısmı, çoğunluğu bazaltik topraklarla kaplı olan Siverek-Viranşehir Platosu'nun düzlük 
alanları oluştururken, güneyde kalan az bir kısmı ise Ceylanpınar ilçe merkezi ve yakın çevresinde yer alan ve aynı isimle anılan Ceylanpınar ovası oluşturmaktadır. Bu geniş tarım alanları, aynı zamanda, Harran Ovası'ndan sonra sulamalı tarımın (halk sulamaları) en yoğun yapıldığı alandır.

İkinci Kuşak; Bu kuşağın doğu sınırı, yukarıda da anlatıldığı gibi, doğu kuşağın batı sınırı olan kuzeybat1-güneydoğu doğrultusunda plato yüzeyindeki tepelik alanlar (Tektek Platosu) oluşturmaktadır. Orta kuşağın batı sınırını kuzeyde Bozova-Şanlıurfa merkez ilçe sınırında plato yüzeyindeki tepelik alanlar ile Şanlıurfa'nın batısında kuzey-güney yönünde Tektek Platosu'na paralel uzanan Fatik Platosu oluşturmaktadır (Şekil 2). Bu kuşağın güney kısmını oluşturan Harran Ovası, Atatürk Barajı'ndan Şanlıurfa Tüneli'yle getirilen su ile sulanmaktadır. Bu kuşağın Şanlıurfa şehrinin kuzeyinde kalan alanlarda, Hilvan'ın batısında sınırlı bir alan hariç, genelde kuru tarım yaygındır.

Üçüncü Kuşak; Bu kuşak, Bozova ilçesi sınırları içinde kalan karstik karakterli Yaylak Ovası ve çevresi ile Suruç ilçesi sınırları içinde yer alan ve aynı isimle anılan alüvyonlu malzeme ile örtülü Suruç Ovası ve bu ovanın kuzeyindeki plato yüzeyinde yer alan düzlükler oluşturmaktadır (Şekil 2). Bu kuşakta Yaylak ve Suruç ovaları ve yakın çevresindeki tarım alanları, diğer kuşaklara nazaran çok sayıda tepe, sırt ve dağlık alanlarla sınırlandırılmaktadır. Bu kuşağın özellikle Birecik-Halfeti arasında çok yoğun bir şekilde fistık ve bağ bahçeleri dikkat çeker.

Ayrıca, Şanlıurfa ilinde bu üç kuşak dışında, vadi tabanı ova niteliğinde olan Birecik şehrinin kuzeyinde yer alan Altınova ve güneyinde yer alan Mezra ovası ile yer yer plato yüzeyindeki düzlükler oluşturmaktadır. Fırat nehrinin doğu yakasında bulunan bu iki vadi tabanı ovaları, çalışma alanımızda özellikle patlıcan, domates ve biber gibi sebze yetiştiriciliği oldukça yaygındır.

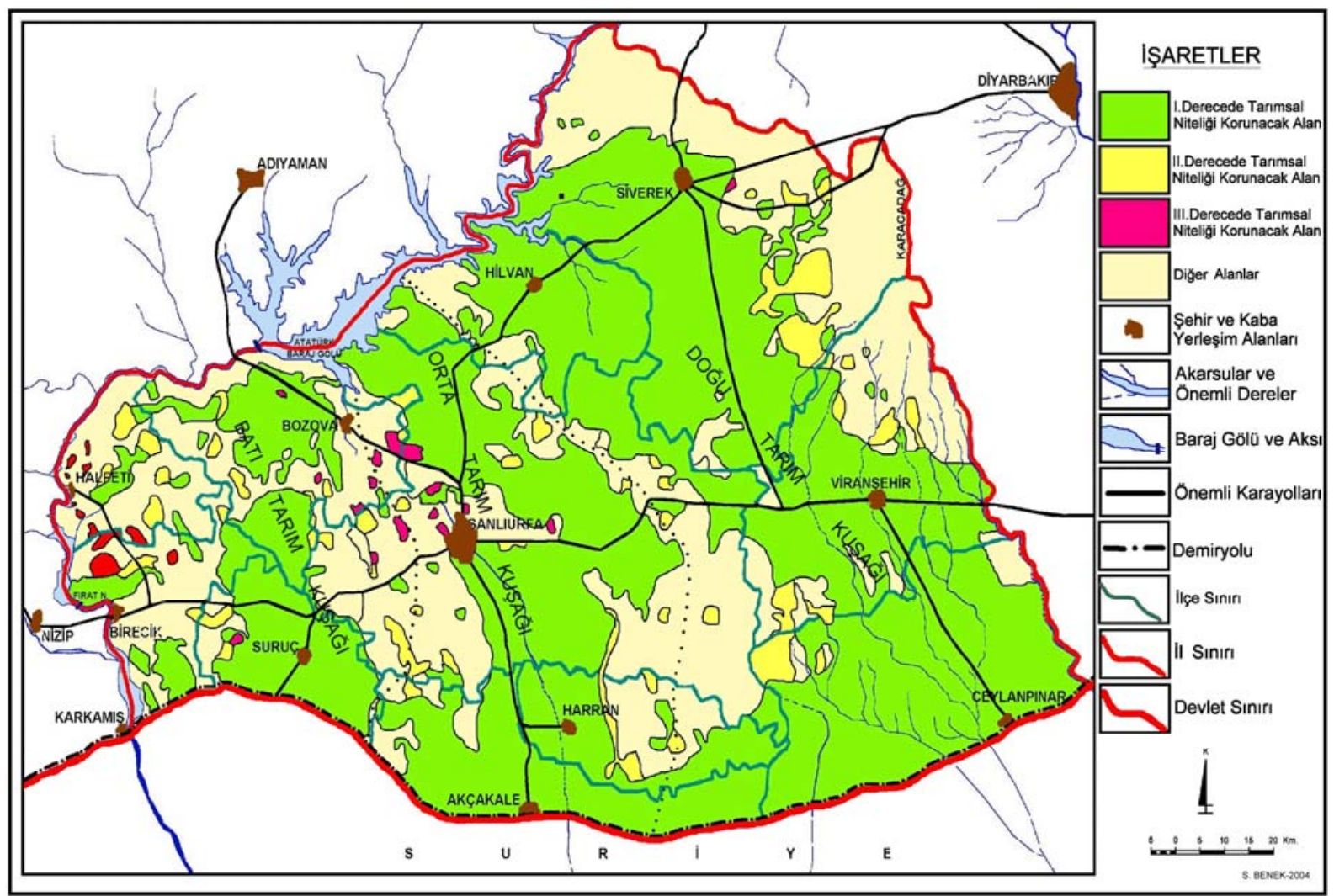

Şekil 2. Sanlıurfa ilinde tarım arazilerinin dereceli olarak tasnifi

Tarım alanlarını tek ve mevsimlik üretim için ayrılmış alanlar (ekili alanlar) ile uzun ömürlü tarımsal bitkilere ayrılmış alanlar (dikili alanlar) şeklinde ele almak mümkündür (Özçağlar, 2000: 124). Şanlıurfa ilinde tarım alanlarının \% 90,2'si (1.083.506 ha) "ekili", \% 9,8'i (117.067 ha) ise 
"dikili” alan olarak kullanılmaktadır. Ekili tarım alanlarının ilçeler bazında dağılışına bakıldığında, en yüksek oranla (\% 99,6) Harran ilçesi birinci sırada, en düşük oranla (\% 41,1) Halfeti ilçesi son sırada yer almaktadır. Başka bir ifade ile, çalışma alanımızda ekili alanlar, dikili alanların yoğun olduğu Birecik, Halfeti ve kısmen de Bozova ilçeleri dışındaki ilçelerde yoğunlaşmakta ve hatta bu ilçelerde (Harran, Akçakale, Ceylanpınar, Suruç, Merkez, Hilvan ve Viranşehir) \% 90'nın üzerine çıkmaktadır (Şekil 3).

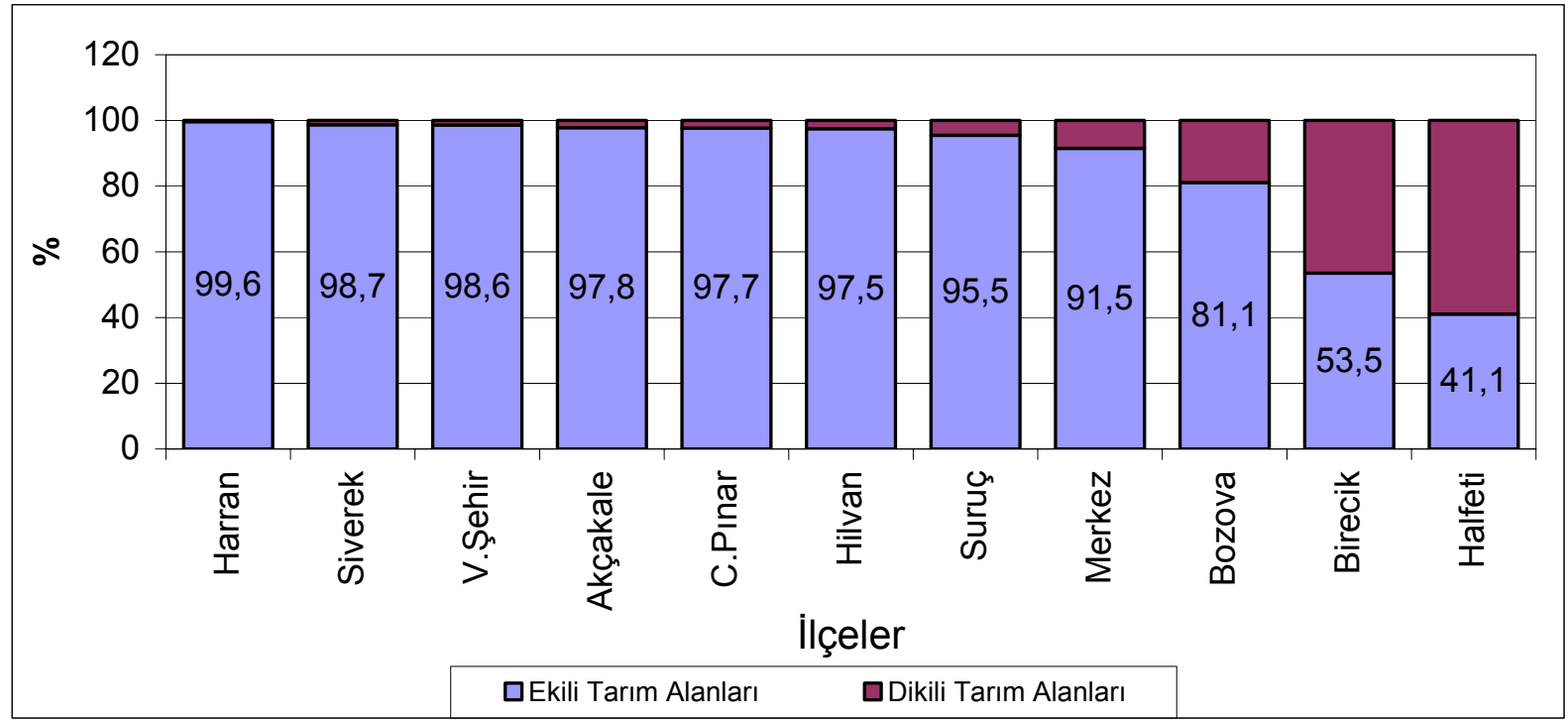

Şekil 3. Şanlıurfa ilinde ilçeler bazında ekili ve dikili tarım alanlarının oranı (\%)

Ekili tarım alanları, Şekil 4'te de görüldüğü gibi, Hilvan ve Viranşehir ilçeleri dışında kalan diğer ilçeler (Harran, Akçakale, Suruç, Ceylanpınar), Harran, Suruç ve Ceylanpınar ovalarının bulunduğu alanlarda yer almaktadır. Bu da, çalışma alanımızda ekili tarım alanlarının daha çok ovalarda yoğunlaşmakta olduğunu göstermektedir (Şekil 4). İlde en çok ekilen tarımsal ürünlerin başında buğday, arpa, pamuk, mercimek, susam, nohut, karpuz, kimyon, biber, mısır, domates ve patlıcan gelmektedir. Bu ürünler içerisinde pamuk, biber, mısır, domataes ve patlıcan sulu şartlarda, diğer ürünler ise ağırlıklı olarak kuru şartlarda ekilmektedir. Ancak, sulama imkanlarının olduğu alanlarda pamuk tarımı ile dönüşümlü olarak sulu şartlarda buğday ve arpa I. ürün, mısır, susam, nohut ve karpuz ise II. ürün olarak yetiştirilmektedir. GAP çerçevesinde yürütülen sulama projeleri tamamlandıkça sulu koşullarda yetiştirilen tarımsal ürünlerin lehine bir genişleme olacaktır. 


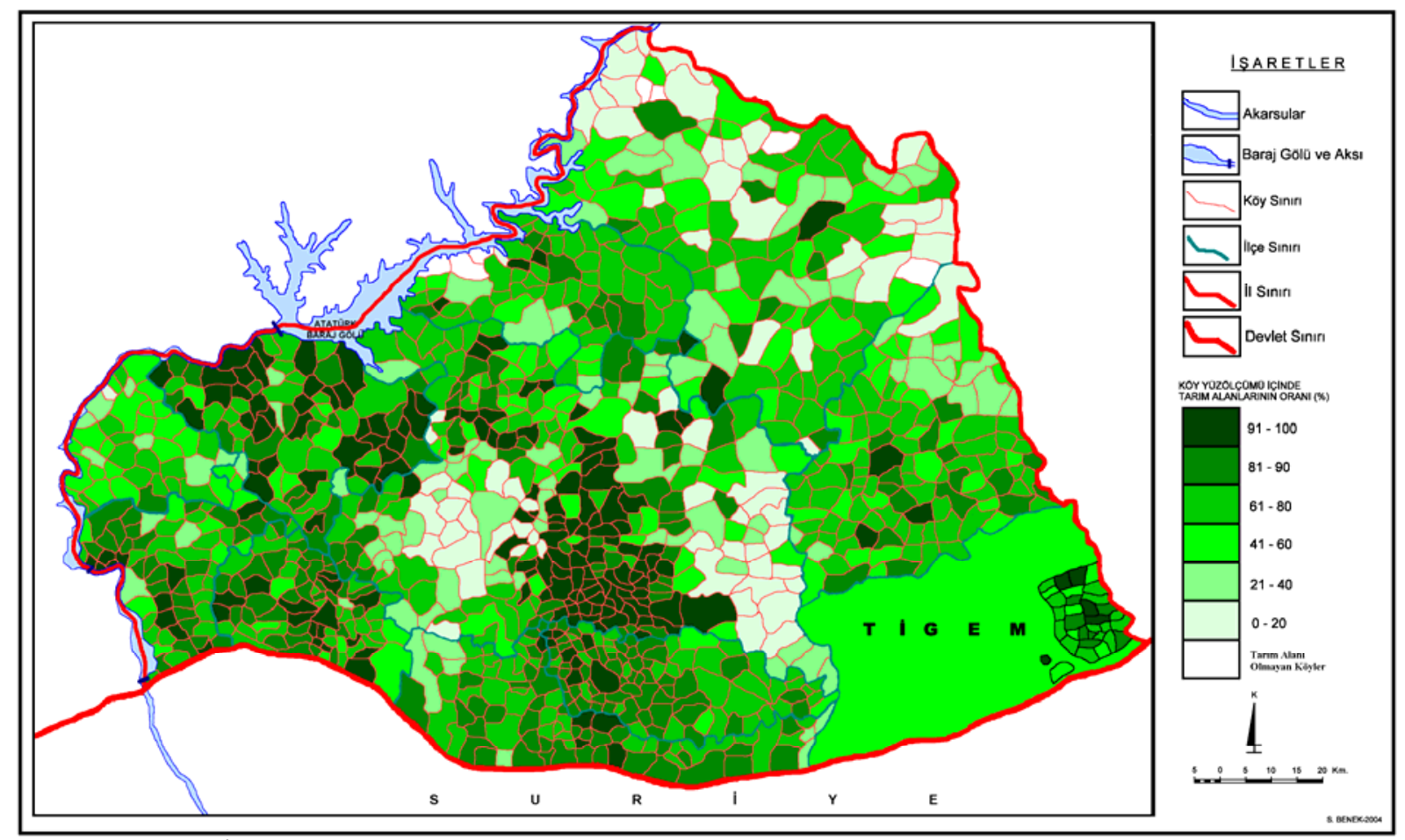

Şekil 4. Şanlıurfa İlinde köy bazında tarım alanlarının dağılışı

Şanlıurfa ilinde dikili tarım alanlarının neredeyse tamamını antepfistığı ile bağ tarım alanları oluşturmaktadır. Dikili alanlar, Şanlıurfa ilinin daha çok batısında yer alan Birecik-Halfeti Platosu'ndaki Halfeti ilçesi $(\%$ 58,9) ile Birecik ilçesi $(\%$ 46,5) ve kısmen de Urfa-Bozova Platosu'nun kuzeyindeki Bozova ilçesinde $(\%$ 18,9) bir dağılım göstermektedir (Şekil 3). Bu alanların en yoğun olduğu yerlerin başında Birecik şehrinden başlayan kuzeye doğru Halfeti ilçesini de içine alarak Fırat nehrine kadar giden alan gelmektedir. Bu alanın yanında Şanlıurfa-Gaziantep ve Şanlıurfa-Bozova karayolu boyunca sağl1-solu adacıklar halinde antepfıstığı ve bağ tarım alanları sıralanmaktadır. Bunun dışında ilde, Tektek Platosu'nun kuzeydoğusunda, Ceylanpınar şehrinin kuzey ve batısında TIGGEM'e ait iki adacık halinde ve başta Hilvan olmak üzere Siverek, Viranşehir ve Suruç ilçelerinde hemen hemen her köyde sinırlı sayıda da olsa adaciklar halinde antepfistığ 1 ve bağ tarım alanları mevcuttur (Şekil 5). 


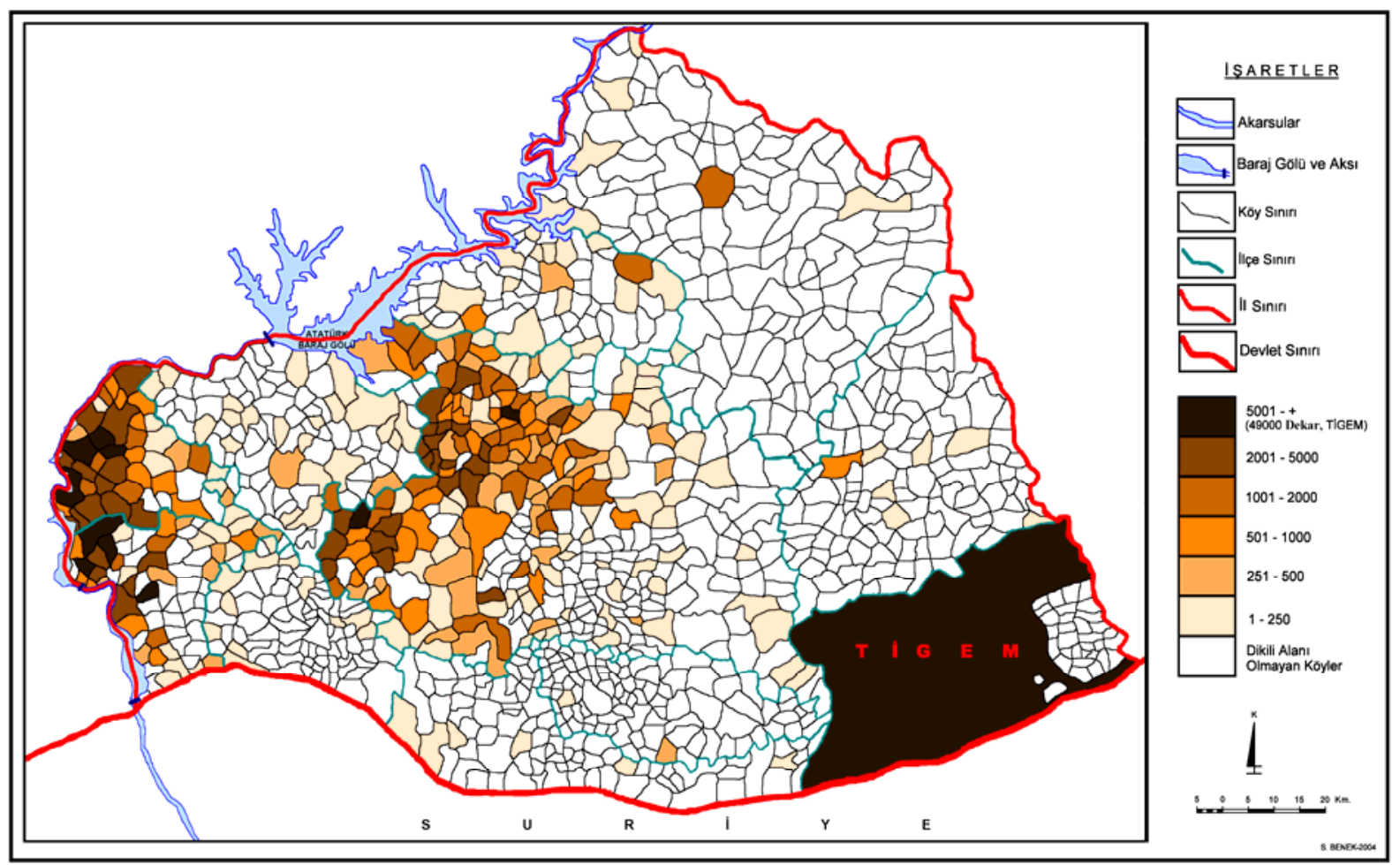

Şekil 5. Şanlıurfa İlinde köy bazında dikili tarım Alanlarının dağılışı

\section{Sulama Durumu}

İl Planlama ve Koordinasyon Müdürlüğü'nün, 2004 yılı verilerine göre, Şanlıurfa ilindeki tarım alanlarının \% 90,3'ü (1.084.755 ha) ekili, \% 9,7'si (117.067 ha) ise dikili alan olarak değerlendirilmektedir. Toplam tarım alanları içerisinde sulanan tarım alanları ekili-dikili alanlar bakımından incelendiğinde, ekili alanların \% 25,9'unda (312.517 ha), dikili alanların ise sadece \% 0,1 'inde (1.249 ha) sulu tarım yapılmaktadır (Çizelge 2).

Çizelge 2. Şanlıurfa ilinde tarım alanlarının

ekili-dikili ve kuru-sulu alanlara dağılıșı (Hektar)

\begin{tabular}{lcc}
\hline Tarım Alanları & Hektar $(\mathrm{Ha})$ & Oranı $(\%)$ \\
\hline Ekili kuru alanlar & 773.487 & 64,4 \\
Ekili sulu alanlar & 311.268 & 25,9 \\
Dikili kuru alanlar & 115.818 & 9,6 \\
Dikili sulu alanlar & 1.249 & 0,1 \\
Toplam & 1.200 .573 & 100,0 \\
\hline
\end{tabular}

Kaynak: İl Planlama ve Koordinasyon Müdürlüğ̈ü, 2004

Güneydoğu Anadolu Bölgesi (dolayısıyla Şanlıurfa ili), genel iklim koşulları göz önüne alındığında, yağış ve sıcaklık koşullarının olumsuzluğu nedeniyle etkili olan şiddetli yaz kuraklığı, bazı yıllarda etkisini yaygınlaştırarak yılın geneline yayılmakta, bazen de birkaç yıl sürmekte ve tarımsal etkinliklerde büyük zararlara neden olmaktadır (1960, 1961 ve 1973 yıllarında olduğu gibi). Kuraklığın tarım alanlarındaki olumsuz etkilerinin ortadan kaldırılması ve gerekli ürün artışının sağlanması için, bölgenin büyük bir bölümünde sulama zorunlu hale gelmektedir (Gürgen, 2002: 145).

Yağmur sularının yetersiz kaldığı dönemlerde, özellikle de yazlık tarımsal bitkilerde su, verim ve dolayısıyla üretim üzerinde artırıcı bir rol oynamaktadır. Daha da önemlisi, çalışma alanımız ve yakın çevresinde olduğu gibi, yaz yağışlarının yetersiz ve ilkbahar yağışlarının da istikrarsız olduğu alanlarda sulamanın ayrı bir yeri vardır. Bu açıdan bakıldığında, özellikle de tarım sektörü açısından GAP'ın önemi bir kez daha anlaşılmış olur. 
$\mathrm{Bu}$ çerçevede yapılan araştırmalara göre, Şanlıurfa ilinde ekili-dikili tarım alanı olan 1.200.573 ha'ın 836.000 ha'1 (\% 69,6) sulamaya elverişli olduğu sonucuna varılmıştır. Çalışma alanımızda GAP'ın direkt ve dolaylı etkisi ile, sulama alanları artmış olup, 2004 yılı itibariyle, sulamaya elverişli ekili-dikili alanların \% 37,4'ü (312.517 ha) sulamalı tarıma açılmıştır. Bu sulamaların; 171.080 hektarı kamu sulaması ve 141.437 hektarı ise halk sulaması şeklindedir (Çizelge $3)$.

Cizelge 3. Șanliurfa ilinde mevcut sulama durumu

\begin{tabular}{lllr} 
& Sulama Türü & Sulama Adı & Sulama Alanı(Ha) \\
\hline Kamu & Baraj Sulamaları* & Şanlıurfa-Harran Ovaları (Kısmi) & 120.000 \\
& & Hacıhıdır Barajı ve Sulaması & 2.080 \\
& Yeraltı Sulamaları* & Akçakale Yeraltı Suları & 15.000 \\
& & Ceylanpınar Yeraltı Suları & 27.000 \\
& & Suruç Yeraltı Suları & 7.000 \\
Özel & Halk Sulamaları** & İl Genelinde & 141.437 \\
Toplam & & & 312.517 \\
\hline \multicolumn{2}{l}{ Kaynak: *GAP İdaresi-**İl Planlama ve Koordinasyon Müdürlüğü, 2004. }
\end{tabular}

Çalışma alanımızda sulamaya açılan alanlarla ilgili olarak, mutlaka büyük bir önemle değinilmesi gereken önemli bir konu da halk sulamalarının gelişim durumudur. Yıllardır geleneksel kuru tarımda umduklarını bulamayan çiftçiler, kamu tarafından sulamaya açılan alanlarda başta pamuk olmak üzere elde edilen yüksek miktardaki artı değerden etkilenmişlerdir. Bu durumda, başta Suruç ilçesindeki çiftçiler olmak üzere yöre çiftçileri, gelecekte sulama olanağına kavuşacak olsalar bile bunu beklemeden, bulundukları yörenin su potansiyelinin durumuna göre farklı yöntemler kullanarak kendi imkanları ile tarlalarını sulamaya açmışlardır. Bu bağlamda, bir kısım yöre çiftçisi yeraltı su kaynaklarını değerlendirerek sulama kuyusu; bir kısım yöre çiftçisi de baraj göletlerinde sulama tesisleri kurup sulama olanaklarını yaratmışlardır. Bu durum, bize, yöre çiftçisinin bir an önce sulu tarım yapma arzularının güçlü ve bir anlamda da zemin oluşturulduğunda girişimci olduğunu göstermektedir. Halk sulamaları sonucunda, neredeyse kamu sulama alanları (171.080 ha) kadar bir alan, sulama (141.437 ha) imkânına kavuşmuştur. Halk sulamalarının en yaygın olduğu alanlar Siverek-Viranşehir platosunda (Siverek, Hilvan ve Viranşehir ilçelerinde), Urfa-Bozova Platosunun batısında Bozova ilçesinin kuzeyinde Atatürk barajı göletinin yakın çevresinde, Suruç Ovası'nda, Fırat vadi tabanındaki Mezra ve Altınova vadi tabanı ovalarındaki tarımsal alanlardır. 


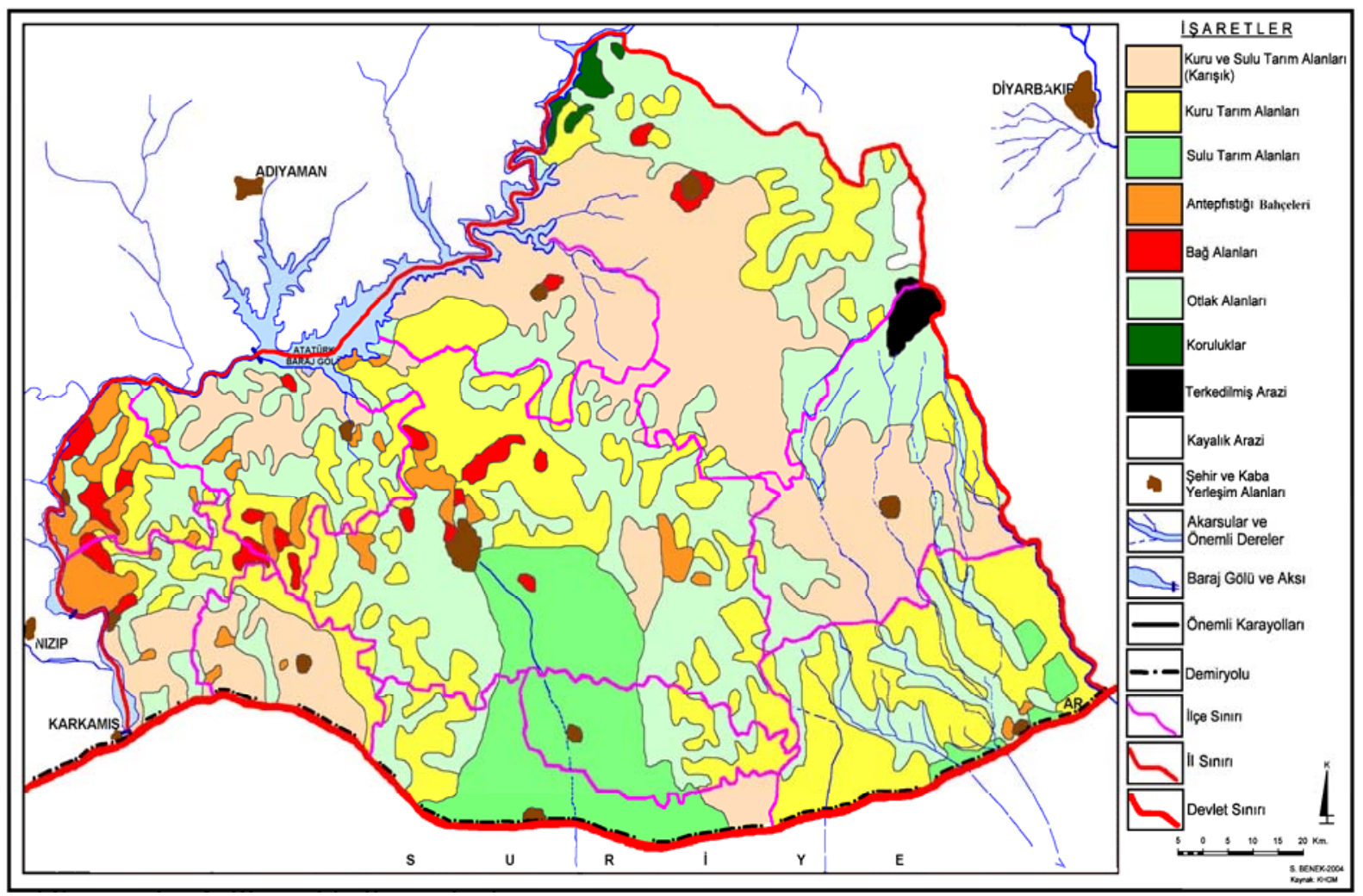

Şekil 6. Şanlıurfa ili arazi kullanım haritası

Çalışma alanımızda, GAP su kaynakları geliştirme programı çerçevesinde sulama amaçlı 10 proje ve bu projelerin sonucunda ise 545561 ha'llk alanın sulanması öngörülmektedir. Bu kamu sulamaları sonucunda net olarak, Şanlıurfa İl Planlama ve Koordinasyon Müdürlüğü'nün bilgilerine göre, yukarıda da belirtildiği gibi, 171.080 ha'lık alan sulamaya açılmış olup, bu da 2004 yılı itibariyle halk sulamaları da dahil sulamaya açılan alanın yarısından fazlasına (\% 54.7), kamu sulamaları çerçevesinde sulamaya açılacak alanın yaklaşık 1/3'üne $(\% 31,4)$, çalışma alanımızda sulanabilir alanın da 1/5'ine (\% 20.5) tekabül etmektedir. Ayrıca, kamu sulamalarının 2/3'ünden (\% 70,1) fazlası Harran Ovası'nda yer almaktadır (Çizelge 4; Şekil 6).

Çizelge 4. GAP su kaynakları geliștirme programı çerçevesinde

Sanliurfa ilinde sulama projeleri ve son durum (2004)

\begin{tabular}{lcl} 
Proje ve Ünitesi & Sulama Alanı (ha) & Proje Durumu \\
\hline I.Aşağ1 Fırat Projesi & 706281 & \\
Şanlıurfa-Harran Sulaması & 151420 & İnşa + İşletme \\
Siverek-Hilvan Pompaj Sulaması & 188778 & Planlama \\
Bozova Pompaj Sulaması & 36699 & Kati Proje \\
Bozova Pompaj Sulaması I. Kısım & 8669 & İnşa \\
II.Suruç-Yaylak Projesi & 114826 & \\
Yaylak Ovası Sulaması & 20012 & İnşa \\
Suruç Ovası Sulaması & 94814 & Planlama-Proje \\
III.Münferit Projeler & 45169 & \\
Akçakale Yer altı Sulaması & 15000 & İşletme \\
Ceylanpınar Yer altı Sulaması & 27000 & İşletme \\
Hacıhıdır Barajı & 2080 & İșletme \\
Bozova Merkez Pompaj Sulaması & 1089 & İnşa \\
Toplam & $545561 *$ & \\
\hline Kaynak: DSI Grame
\end{tabular}

Kaynak: DSİ Genel Müdürlüğü

*Sadece Şanlıurfa ilindeki sulamaları kapsamaktadır 


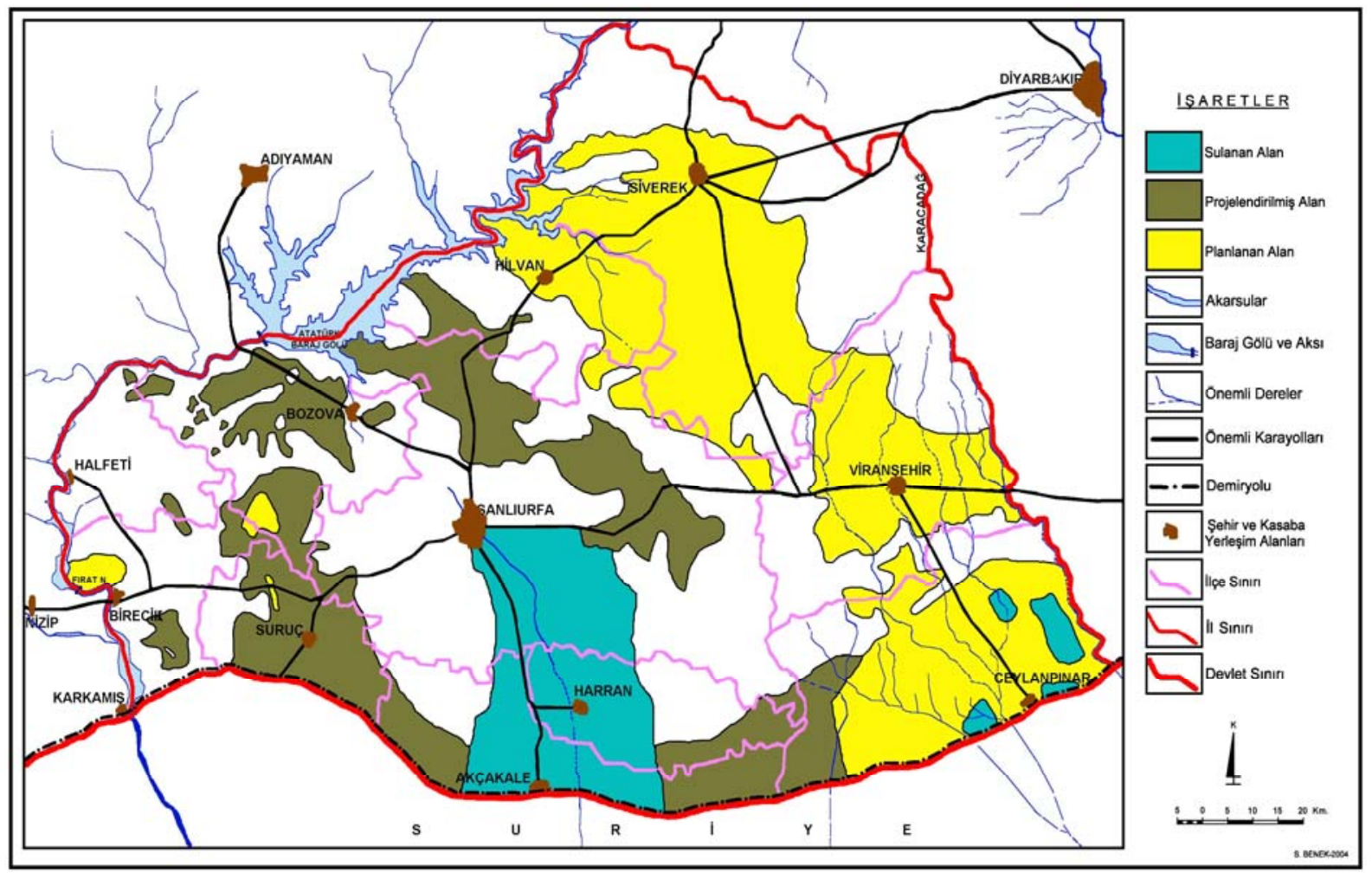

Şekil 7. Şanlıurfa ilinde tarımsal amaçlı sulama projelerin bulunduğu aşamaya ilişkin son durum (2004)

Şanlıurfa ilinin tarımında yaşanan önemli sorunlarından birisi de nadas olayıdır. Nadasın temel nedeni, yaz döneminde sıcaklık değerlerinin çok yüksek ve yağışların da yok denecek kadar az olması nedeniyle yaşanan yaz kuraklığıdır. Böylece, bir tarla kuru koşullarda üst üste ekilmek suretiyle verimsizleşmekte, üretim ve verim düşmektedir. $\mathrm{Bu}$ durumda, yöre çiftçileri, verimsizleşen tarlayı sürerek bir yıl boyunca herhangi bir ürün ekilmeksizin boş bırakmaktadır. Ancak, ertesi yıl yağışların yetersiz olması durumunda yine de düşük seviyede bir üretim gerçekleşmektedir.

İlde kuru koşulların hakim olduğu alanlarda, yıldan yıla nadasa ayrılan tarım alanlarının oranı değişmektedir. Bunun temelinde yıldan yıla değişen miktarlarda düşen yağış miktarından kaynaklanmaktadır. Bu durumda, çalışma alanımızda nadas olayını ortadan kaldırmak veya en aza indirebilmek için, çizelge 4'te de görüldüğü gibi, GAP su kaynakları geliştirme programı çerçevesinde inşaat, proje ve plan aşamasında olan sulama projeleri bir an önce tamamlanarak sulama imkanları artırılmalidır.

Çalışma alanımızda karşılaşılan diğer önemli bir sorun da bilinçsizce yapılan sulamalar sonucu meydana gelen tuzlanma sorunudur. Bunun nedeni ise, "Şanlıurfa'daki Harran ve Suruç ovalarında toprağın altında tuzun bulunmasıdır. Yeterli drenaj önlemleri alınmazsa, sulama arttıkça bu tuzlar yüzeye doğru yükselecektir" (Dizdar, 2003:273). Nitekim, 1960'lı yıllardan beri Akçakale ilçesinin kuzey ve kuzeydoğusunda yeraltı sularından yararlanılarak sulamaya açılan alanlarda (14500 ha), bilinçsizce yapılan sulamalar sonucu, topraklar bugün çoraklaşmayla karşı karşıyadır. Sahada yaptığımız gözlemlerde bilinçsizce yapılan sulamalar sonucunda, sulamadan arta kalan suların tarlanın belirli yerlerinde biriktiği, bu biriken suların yüksek sıcaklıklardan dolayı aşırı buharlaşma ve dolayısıyla kılcallaşma olaylarının etkisiyle tuzlanmaya sebep olduğu görülmüştür (Foto 1). Önlem alınamadığı takdirde, bu durum doğal olarak çoraklaşmaya neden olabilecektir. Sulama sezonu boyunca sulamadan dönen fazla suların drenaj kanallarıyla uzaklaştırılması gereklidir. 


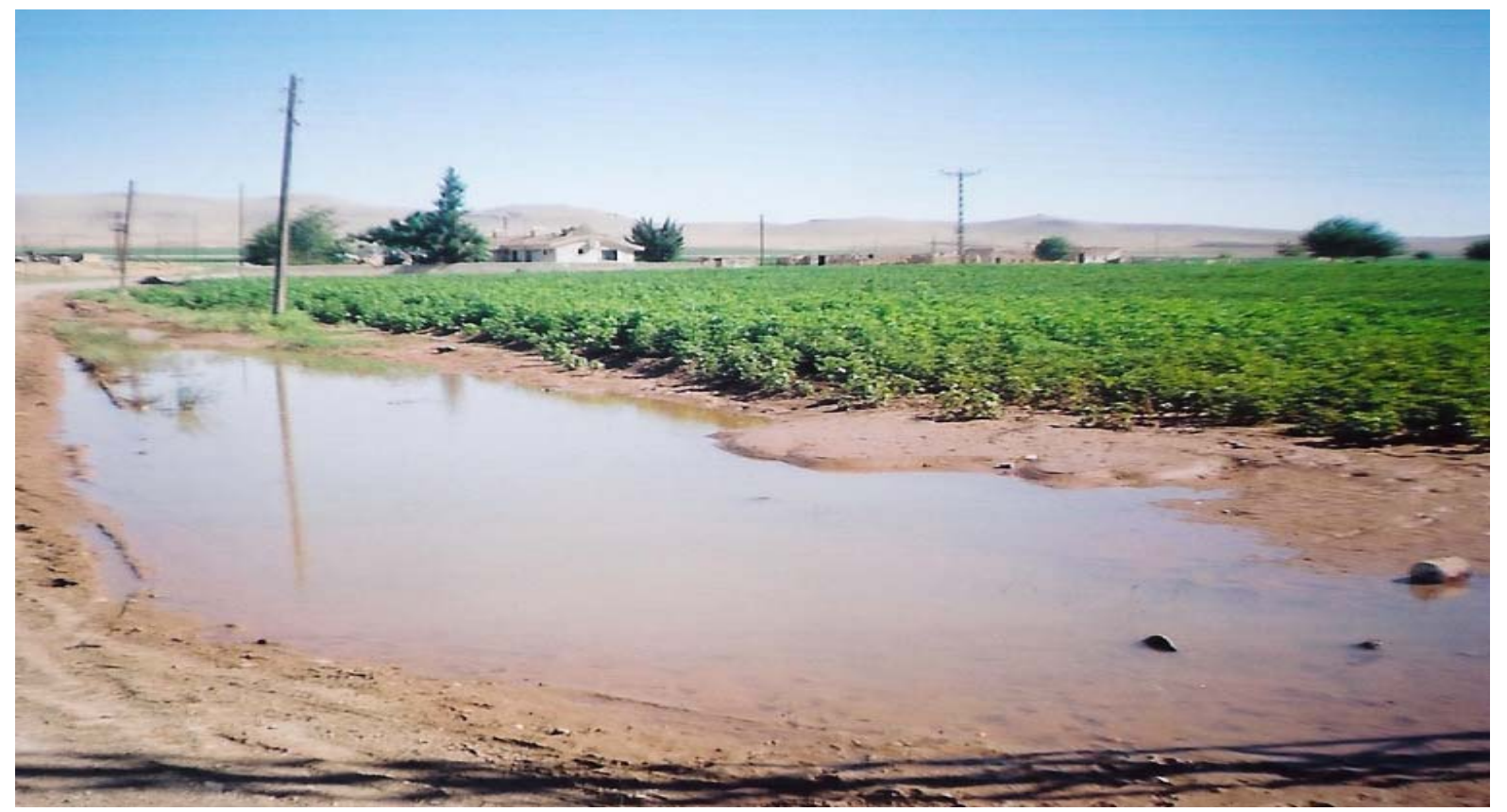

Foto 1: Harran Ovası'nın kuzeyinde Şanlıurfa-Mardin yolu kenarında sulamadan arta kalan suların tarlanın hafif çukurlu alanda toplanmas1

\section{Tarımsal İșletme Sayısı, Parsel Büyüklüğü ve Mülkiyet Sorunu}

Türkiye'de tarımsal yapının temel problemlerinden ve hatta en önemlilerinden birisi de işletme sayısı, parsel büyüklüğü ve mülkiyet sorunudur. Bu yapısal sorun, Güneydoğu Anadolu Bölgesi’nde ve özellikle çalışma alanımız olan Şanlıurfa ilinde daha derinleşmektedir. Söz konusu alanda çalışmalar yapan ilgili kamu kuruluşu olan Türkiye İstatistik Kurumu'ndan (TÜíK) alınan veriler incelendiğinde, tarımsal işletmelerin sayısına, parsel büyüklüğüne ve mülkiyet durumuna ilişkin son durum halen sorunsallığını korumaktadır.

2001 Genel Tarım Sayımı (GTS) Tarımsal İşletmeler (hane halkı) Anketi (DİE, 2003: 4) sonucuna göre, Türkiye genelinde ortalama işletme büyüklüğü 61,01 dekar olarak belirlenmiştir. İller bazında ortalama işletme büyüklüğü incelendiğinde, 11,51 dekarla Rize ilinde en düşük, 194,85 dekarla Şanlıurfa ilinde en yüksek ortalama işletme büyüklügü ortaya çıkmaktadır. Bu durumun ortaya çıkmasında birinci derecede etkili olan faktör, Şanlıurfa ilinin yer şekilleri bakımından Rize iline göre çok sade, düz (genellikle palto konumunda) ve geniş olması etkili olmaktadır. Böylece Şanlıurfa ilindeki ortalama tarımsal işletme büyüklüğünün (194,85 dekar), Türkiye ortalamasının (61,01 dekar) 3.2 katı kadar olduğu görülmektedir (Çizelge 5).

$\mathrm{Bu}$ çerçevede yapılan değerlendirmeler, Şanlıurfa ilinde, Türkiye ortalamasına göre çok çarpıcı sonuçlar ortaya çıkarmaktadır. Buna göre, bu alanda 10 dekar ve altındaki büyüklüğe sahip işletmelerin oranı $\%$ 5,7 ve bu işletmelerin sahip olduğu arazi miktarının da \% 0,3 gibi çok düşük bir oranda kalmaktadır. Türkiye ortalamasına göre, bu gruptaki işletme sayısının oranı $\% 16,1$ ve bu işletmelerin sahip olduğu arazi miktarı ise işletme sayısına oranla düşerek \% 1,4'e inmektedir. 10-49 dekar arasında araziye sahip işletme sayısının oranı Şanlıurfa ilinde $1 / 4$ 'ü (\% 25) ve bu işletmelerin sahip olduğu arazi miktarı da \% 3.6; bu durum Türkiye ortalamasına göre işletme sayısının yaklaşık $2 / 3$ 'üne $(\% 64,8)$ ve bu işletmelerin sahip olduğu arazi miktarının ise 1/5'ine (\% 21,3) tekabül etmektedir (Çizelge 5). Başka bir ifade ile, Şanlıurfa ilinde küçük işletme (1-49 dekar) olarak kabul edilen işletme sayısının oranı \% 25 ve bu işletmelerin sahip olduğu arazi miktarının oranı ise \% 3.6; orta işletme (50-199 dekar) olarak kabul edilen işletme sayısının oranı \% 50,1 ve bu işletmelerin sahip olduğu arazi miktarı ise \% 25,7; büyük işletme (200 ve üzeri dekar) olarak kabul edilen işletme sayısının oranı \% 24,9 ve bu işletmelerin sahip olduğu arazi miktarı ise \% 70,7'dir. Türkiye'de küçük 
işletme sayının oranı $\% 64,8$ ve sahip olduğu arazi miktarı $\% 21,3$; orta işletme sayısının oranı $\% 29,4$ ve sahip olduğu arazi miktarı \% 44,5; büyük işletme sayısının oranı $\% 5,9$ ve sahip olduğu arazi miktarı ise \% 34.2'dir (Çizelge 5). Bu durumda, Şanlıurfa ili, işletme büyüklüğü bakımından Türkiye ortalamasının çok üzerinde bir durum sergilemektedir.

Çizelge 5. Türkiye ve Şanlıurfa ilinde ișletme büyüklük gruplarının dağılımı (dekar)

\begin{tabular}{|c|c|c|c|c|c|c|c|c|}
\hline \multirow{3}{*}{$\begin{array}{l}\text { İşletme } \\
\text { Büyüklüğü } \\
\text { (Dekar) }\end{array}$} & \multicolumn{4}{|c|}{ Türkiye } & \multicolumn{4}{|c|}{ Şanlıurfa } \\
\hline & \multicolumn{2}{|c|}{1991} & \multicolumn{2}{|c|}{2001} & \multicolumn{2}{|c|}{1991} & \multicolumn{2}{|r|}{2001} \\
\hline & $\begin{array}{c}\text { İşletme Sayıs1 } \\
(\%)\end{array}$ & $\begin{array}{c}\text { Arazi (Da) } \\
(\%)\end{array}$ & $\begin{array}{c}\text { İşletme Sayısı } \\
(\%)\end{array}$ & $\begin{array}{c}\text { Arazi (Da) } \\
(\%)\end{array}$ & $\begin{array}{c}\text { İşletme Sayısı } \\
(\%)\end{array}$ & $\begin{array}{l}\text { Arazi (Da) } \\
(\%)\end{array}$ & $\begin{array}{c}\text { İşletme Sayısı } \\
(\%)\end{array}$ & $\begin{array}{c}\text { Arazi (Da) } \\
(\%)\end{array}$ \\
\hline $0-49$ & 67.1 & 22.2 & 64.8 & 21.3 & 28.1 & 4.4 & 25.0 & 3.6 \\
\hline $50-199$ & 27.6 & 40.9 & 29.4 & 44.5 & 51.0 & 29.4 & 50.1 & 25.7 \\
\hline $200-499$ & 4.4 & 19.8 & 5.1 & 22.8 & 14.3 & 23.8 & 19.2 & 27.3 \\
\hline $500-999$ & 0.6 & 6.4 & 0.6 & 6.1 & 4.2 & 16.5 & 4.1 & 14.7 \\
\hline $1000+$ & 0.3 & 10.7 & 0.2 & 5.3 & 2.4 & 25.9 & 1.6 & 28.7 \\
\hline Toplam & 100.0 & 100.0 & 100.0 & 100.0 & 100.0 & 100.0 & 100.0 & 100.0 \\
\hline
\end{tabular}

Kaynak: 2001 GTS tarımsal işletmeler (hanehalkı) anket sonuçları, 2003.

Tarımda, mevcut tarımsal işletmelerin parsel büyüklüğü ve mülkiyet dağılımındaki dengesizlik ile az toprak veya topraksız köylülerin varlığı nedeniyle, çalışma alanımızda "kiracılık", "ortakçılık" gibi farklı işletme tiplerini ortaya çıkarmıştır. Bu bağlamda, 1997 Köy Envanterine göre, 3554 aile kiracılıkla, 1877 aile de ortakçılıkla olmak üzere toplam 5431 topraksız çiftçi ailesi, tarımsal amaçlı kiracılık ve ortakçılık yaparak tarımla uğraşmaktadır (Çizelge 6). Bu topraksız ailelere az topraklı aileler de eklenince, çalışma alanımızda 2188 topraklı çiftçi aile, 5431 ise topraksız çiftçi aile olmak üzere toplam 7619 çiftçi aile kiracılık veya ortakçılık işletme şeklinde tarımla uğraşmaktadır. Kiracılık ve ortakçılıkla uğraşan çiftçi aile sayısı (7619 çiftçi aile), toplam çiftçi aile sayısının (50974 çiftçi aile) \% 15'ıne tekabül etmektedir (Çizelge 6). Bu tarımsal işletme tipi, bir taraftan az veya topraksız çiftçi ailelerin tarımla geçimlerini sağlama imkanını verirken, diğer taraftan toprak açısından bakıldığında, çeşitli olumsuzlukları ortaya çıkarmaktadır. Sahada yaptığımız gözlem ve görüşmelerde, bu tip işletmelerde ortakçı veya kiracı konumundaki çiftçi ailelerin toprağa ilişkin ileriye dönük yatırımlara girişmediği; yanlış ve yoğun kullanımdan dolayı belli bir süre sonra toprağın verimsizleşmesine neden olabildiği tespit edilmiştir.

\begin{tabular}{|c|c|c|c|c|c|c|c|c|}
\hline \multirow[b]{2}{*}{ İlçe } & \multicolumn{3}{|c|}{ Kiracılık } & \multicolumn{5}{|c|}{ Ortakçılık } \\
\hline & $\begin{array}{c}\text { topraklı } \\
\text { çiftçi aile } \\
\text { sayısı }\end{array}$ & $\begin{array}{c}\text { işlenen } \\
\text { arazi (dekar) }\end{array}$ & $\begin{array}{l}\text { topraksız çiftçi } \\
\text { aile sayısı }\end{array}$ & $\begin{array}{l}\text { işlenen } \\
\text { arazi (dekar) }\end{array}$ & $\begin{array}{r}\text { topraklı } \\
\text { çiftçi aile } \\
\text { sayısı }\end{array}$ & $\begin{array}{c}\text { işlenen } \\
\text { arazi (dekar) }\end{array}$ & $\begin{array}{l}\text { topraksız çift } \\
\text { aile sayısı }\end{array}$ & $\begin{array}{l}\text { çi işlenen } \\
\text { arazi (dekar) }\end{array}$ \\
\hline Merkez & 221 & 21.165 & 300 & 22.923 & 44 & 16.962 & 302 & 42.354 \\
\hline A.Kale & 278 & 13.484 & 560 & 20.096 & 123 & 22.810 & 237 & 19.913 \\
\hline Birecik & 24 & 4.480 & 1 & 150 & 412 & 11.650 & 29 & 2.280 \\
\hline Bozova & 129 & 18.105 & 14 & 19.269 & 80 & 11.587 & 35 & 2.640 \\
\hline C.Pinar & 63 & 2.915 & 1.559 & 86.698 & 16 & 640 & 171 & 9.608 \\
\hline Halfeti & 115 & 1.500 & 59 & 1.000 & 17 & 735 & 8 & 520 \\
\hline Harran & 196 & 12.349 & 385 & 22.168 & 85 & 6.999 & 378 & 19.536 \\
\hline Hilvan & 21 & 17.000 & 1 & 150 & 34 & 23.000 & 282 & 61.501 \\
\hline Siverek & 25 & 4.545 & 594 & 74.326 & 9 & 1.480 & 244 & 29.367 \\
\hline Suruç & 11 & 870 & 34 & 1.185 & 128 & 6.614 & 56 & 4.745 \\
\hline V.Şehir & 12 & 2.462 & 47 & 13.772 & 145 & 45.800 & 135 & 19.090 \\
\hline Toplam & 1.095 & 98.875 & 3.554 & 261.737 & 1.093 & 148.277 & 1.877 & 211.554 \\
\hline
\end{tabular}

Kaynak: TÜİK, Şanlıurfa 1997 Köy Envanteri, Şubat 2002.

\section{Arazi Toplulaştırma ve Tesviyesi}

Toprak reformunun belli başlı türlerinden birisi de arazi toplulaştırmasıdır. Toprakların yeniden dağıtımı anlamına gelen toplulaştırma çalışmalarını Tümertekin, kapsamı itibariyle dar ve geniş olmak üzere iki şekilde ele almaktadır. Dar anlamda toplulaştırma, şahısların ya da çiftçi ailelerinin mülkiyetinde bulunan ve parçalanmış, çeşitli yerlere dağılımış tarlaların bir araya getirilerek 
düzenli şekiller halinde toplulaştırmasıdır. Geniş anlamda ise, toplulaştırmak için ele alınan alandan azami gelir sağlamak, tarımsal yapıyı geliştirmek ve çiftçi ailelerinin yaşama düzeyini yükseltmek için teknik, ekonomik ve toplumsal yönden gerekli önlemleri almaktır (Tümertekin, 1999: 202).

Toplulaştırma; köy, belde veya havza esas alınarak o yerin sınırları içerisindeki gerçek ve tüzel kişilere ait arazilerin teknik, ekonomik, sosyal ve hukuki yönleri incelenerek uygulanır (TRGM, 2003: 11). Arazi toplulaştırma alanında toplulaştırma işleminden sonra toprak sahibine önceki arazisine eşit değerde arazi verilebilmesi için, mevcut parsellerinin belirli ölçütlere göre derecelendirme işlemlerinin yapılması gereklidir. Arazi derecelendirmesi, arazinin verim yeteneğini tahmin etme işlemi olup, genelde çeşitli arazi kullanım türlerinin gereksinimleriyle arazinin sahip olduğu niteliklerin kıyaslanması, diğer bir anlatımla arazinin toprak, topografya ve diğer özelliklerinin yorumlanmasına dayanan, belli değerlendirme biçimleri arasında karşılaştırma yapabilmek amacıyla gerçekleştirilen çalışmaları içermektedir (Gündoğdu ve Arkadaşları, 2004: 137-148).

Arazi toplulaştırma çalışmaları öncelikle sulamaya açılan alanlarda başlatılmıştır. Bu nedenle, Harran Ovası'nda yer alan Merkez ilçesinin 85 köyünde, Harran ilçesinin 61 köyünde ve Akçakale ilçesinin ise 18 köyünde olmak üzere toplam 164 köyde arazi toplulaştırma çalışmaları tamamlanmıştır. Ovada 91 köyde ise arazi toplulaştırma çalışmaları devam etmektedir. Arazi toplulaştırma çalışmaları biten diğer bir alan ise Ceylanpınar ovasıdır. Ceylanpınar ilçesinde tüm köyleri (43 köy) kapsayan arazi toplulaştırma çalışmaları tamamlanmıştır (Çizelge 7). Bütün bu projelerden sonra, GAP İdaresi'nin 2003 Y1l Faaliyet Raporu (GAP-BKI, 2003: 13)'na göre, Harran Ovası'nda 108463 ha alanda ve Ceylanpınar'da 9000 ha alanda arazi toplulaştırma çalışmaları tamamlanmıştır. Harran Ovası'nda 57780 ha, Yaylak Ovası'nda 18500 ha ve Bozova ilçesinde 27160 ha'lık alanda arazi topulaştırma işlemleri Tarım Reformu genel Müdürlüğü tarafindan ihale edilmiş olup, çalışmalar devam etmektedir.

Cizelge 7. Sanlıurfa ilinde arazi toplulaștırma çalıșmaları yapılan köylerin ilçelere dağılımı

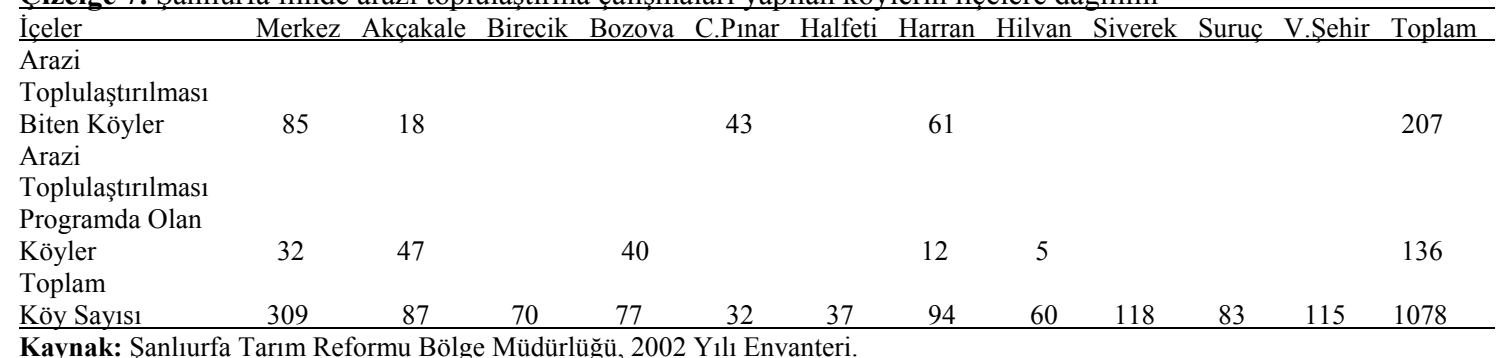

Çalışma alanımızda toplulaştırma çalışmalarını zorunlu kılan en önemli temel faktör, TÜİK'in çalışma alanımıza ilişkin saptadığ 1 mevcut tarım işletmelerinin parçalılık durumudur. Bu çalışmaya göre, çalışma alanımızda 1 ile 5 parçaya sahip işletmelerin oranı $\% 85$ olup, Türkiye ortalamasının (\% 66) çok üzerinde, 6 arazi parçasına sahip işletmeler bakımında ise, Şanlıurfa ili (\% 15) Türkiye ortalamasının (\% 34) altında bir durum arz etmektedir (Çizelge 8). İşletmelerin sahip olduğu parçalılık durumu, gerek Şanlıurfa ilinde gerekse Türkiye'de hem tarımsal verimliliği olumsuz anlamda etkilemekte hem de zaman ve ekonomik anlamda israfa neden olmaktadır. $\mathrm{Bu}$ tablo, çalışma alanımızda tarımsal arazinin parçalılık durumunun ortadan kaldırılması ve verimli tarımsal faaliyetlerinin bir an önce yürütülmesi için arazi toplulaştırma çalışmalarının büyük bir önem taşıdığını göstermektedir. 


\begin{tabular}{lccc}
\multicolumn{4}{l}{ Cizelge 8. Mevcut tarım ișletmelerinin parçalılik durumu } \\
\hline İşletme Alanı (da) & \multicolumn{4}{c}{ Arazi Parça Sayısı } \\
& $1-5$ & $6-9$ & $10+$ \\
\hline $1-49$ & 16722 & 850 & 509 \\
$50-99$ & 17247 & 139 & - \\
$100-499$ & 18145 & 3205 & 2103 \\
$500+$ & 3014 & 214 & 1060 \\
Toplam & 55129 & 5608 & 3672 \\
Oran (\%) & 85 & 9 & 6 \\
Türkiye & & & 15 \\
Ortalaması (\%) & 66 & 19 &
\end{tabular}

Kaynak: TKB, Şanlıurfa Tarım Master Plan, s. 107, 2002.

Çalışma alanımızda arazi toplulaştırma ve tesviyesi çalışmaları, öncelikli olarak sulamaya açılan alanlarda yapılmakta ve sulamaların ilk dönemlerinde ciddi karışıklıklara neden olmaktadır. Dolayısıyla arazi düzenlenmesine yönelik bu tür çalışmaları, sulama faaliyetleri başlamadan önce tamamlanması, tarımsal verimlilik açısından önem arz etmektedir.

Verimlilik üzerinde önemli rol oynayan diğer önemli bir konu ise, en az arazi toplulaştırma çalışmaları kadar gerekli ve bir o kadar zorunlu olan arazi tesviyesidir. Bu durum özellikle eğimin az olduğu ovalarda daha da önem taşımaktadır. Harran ovasında toplam 126 köyde 60643 ha alanı kapsayan 8 arazi tesviyesi projesi planlanmış ve 2004 yılı itibariye bu projelerin 5'i tamamlanmış, 2'si devam etmekte ve 1'i ise halen planlama aşamasındadır. Şanlıurfa ilindeki tarım alanlarında yer yer tuzlanmaya müsait alanların bulunması ve bunun yanında sulamalı tarım açısından bilinçsiz olan yöre çiftçilerinin tutumu da eklenince, sulamaya açılan/açılacak alanlarda arazi düzenlemesi çalışmaları daha da önem kazanmaktadır.

\section{Sermaye Durumu}

Çalışma alanımızda mevcut tarımsal yapının temel sorunlarından birisi de sermaye yetersizliği ve dengesiz dağılımı sorunudur. Şanlıurfa ilinin tarımsal yapısı içerisinde sermayenin önemli bir sorun olarak yer işgal etmesi, beraberinde bir çok sorununun da çözüm adresi olarak sermayenin gösterilmesi bu konunun önemini ortaya koymaktadır. Şanlıurfa ilinde sermaye sorununu önemli kılan diğer önemli bir unsur ise, sermaye yetersizliği yanında var olan sermayenin dağılımında çok dengesiz bir durum arz etmesidir. Bu sermaye dağılımındaki dengesizliğin temelinde, büyük oranda çalışma alanımızdaki toprak mülkiyeti dağılımı bulunmaktadır. İlde faaliyet gösteren tarım üreticilerin yaklaşık 1/3'ü topraksız veya az topraklı üretici konumundadır.

Sermaye yetersizliği, tarımsal yapının bir çok konuda modernleşmemesine neden olmaktadır. Karlı, "Kooperatifçilik ve Diğer Örgütlenme Modellerine İlişkin Genel Çerçeve" adlı çalışmasında sermaye yetersizliği sonucunda tarımsal yapının yaşadığı sorunlara ilişkin şu saptamayı yapmaktadır: Ülkemizde tarım işletmelerinin çoğunun yeter büyüklükte olmaması ve sermaye birikimi sağlayamaması nedeni ile işletmelerde; gerekli yatırımlar yapılamamakta, tarımsal girdi kullanımı yaygınlaştırılamamakta ve modern tarım teknolojileri uygulanamamaktadır (Karlı, 2001: 12).

GAP İdaresi-TÜBITAK tarafından yapılan bir araştırmaya göre, Şanlıurfa ilinde tarımla uğraşan üreticilerin \% 43'ü kredi kullanmıştır. Kredi kaynaklarına bakıldığında, kullanılan kredinin \% 32'sini Ziraat Bankası'ndan, \% 7's1 Tarım Kredi Kooperatiflerinden ve \% 61'ini ise tüccar ve şahıslardan aldıkları belirtilmektedir (Öztürkmen, 2003: 158). Burada belirtilmelidir ki, tüccar ve şahıslardan alınan kredilerin kısa süreli ve faiz oranları da oldukça yüksektir. Bunların büyük bir kısmı tefeci konumundadir.

Sulamalı tarımla birlikte üreticiler zorunlu olarak daha fazla girdi kullanımına gitmekte ve dolayısıyla sermaye konusunda çok ciddi sorunlar yaşamaktadırlar. İşte sermaye sıkıntısı içerisinde olan bu üreticiler, söz konusu ekonomik sıkıntılarını gidermek için, yukarıda da belirtildiği gibi, çok büyük bir oranda (yaklaşı 2/3) tefecilere başvurmakta ve bu da yeni sorunların ortaya çıkmasına neden olmaktadır. Çalışma alanımızda özellikle pamuk tarımının gelişmesi ve yaygınlaşması ile birlikte tefecilik oranı da artmıştır. Bu konuda elimizde net olarak herhangi bir istatistiki veri yoktur. 
Açığa para verme anlamına gelen tefecilik, özellikle kötü ürün yıllarında artmakta ve çiftçiyi çok güç durumda bırakmaktadır. Bunlar genelde köyden kente gelip yerleşen ve tarımla ilişkisi olan tüccarlardan meydana gelmektedir. Çalışma alanımızdaki pamuk üreticileri daha çok pamuğun yetişme devresi boyunca gerekli olan yatırım giderlerini karşılamak nedeni ile tefeciye baş vurmaktadır. Para isteme tarihi ile pamuk toplama mevsimi arasındaki zaman farkına göre değişmekle birlikte pamuk karşılı̆̆ında çiftçiye para verilmektedir. Tefeci, bir önceki yılın fiyatına göre para öder. Sermaye kaynaklı bu temel sorunu gidermek ve dolayısıyla çiftçilerin tefecilere başvurmamaları için uygun ödeme imkanı sağlanarak devlet tarafından krediler sağlanmalıdır.

Çalışma alanımızda sermaye sorununu çözmek veya en aza indirmek amacıyla, öncelikle kredi kullanımındaki bürokratik işlemler azaltılmalı ve tarımla uğraşıp da topraksız veya az topraklı olanlara da kredi imkânı sağlanmalıdır. Ayrıca, Tarımsal Kredi Kooperatiflerinin sayısı artırılmalı ve etkinleştirilmelidir.

\section{7. Çiftçi Örgütlenmesi}

Kırsal alanda yaşayan ve tarımsal üretim faaliyetinde bulunan üreticilerin; var olan üretim kaynaklarını daha etkin kullanabilmeleri, tarımsal girdileri uygun koşullarda temin edebilmeleri, modern tarım teknolojilerini uygulayabilmeleri, ürünlerini en iyi şekilde değerlendirerek pazarlayabilmeleri ve kamu hizmetlerinden daha etkin yararlanabilmeleri yeterince örgütlenmeleri ile mümkündür (Karl1, 2001: 12). Tarımda çiftçi örgütlenmesi, kurumsal olarak çiftçinin gelirini yükselten en önemli öğelerden birisidir. Çiftçi örgütlenmesi gelişmiş ve gelişmekte olan ülkelerde tarım kesiminin bütünsel olarak gelişmesinde önemli bir rol oynar.

Tarım sektöründe, tarımsal yapı ile ilgili sorunları çözmeyi ve tarımı modernleştirmeyi amaç edinen kalkınma araçlarını, İnan, "teknolojik değişimler", "kurumsal reformlar" ve "üretici örgütlenmesi" olmak üzere üç grupta toplamaktadır. Tarım üreticilerinin örgütlenmesi durumu hem tarımsal pazarlama hizmetlerinin etkinleştirilmesini hem de kurumsal reformların ve teknolojik yeniliklerin uygulanmasını kolaylaştırmaktadır (İnan, 2003: 171). Bu nedenlerden dolayı çalışma alanımızın kırsal kesiminde gerek geleneksel tarım faaliyetlerinin etkin olması gerek toplumsal yapının feodal ağırlıklı bir yapı arz etmesi ve bunun sonucunda ortaya çıkan az ve topraksız tarımsal üreticilerin varlığı, tarım sektöründe örgütlenme ihtiyacını daha da zorunlu hale getirmektedir.

Türkiye genelinde olduğu gibi, çalışma alanımızdaki üretici örgütlerini de mesleki örgütler (Ziraat Odaları, Çiftçi Dernekleri), ekonomik örgütler (Tarım Kredi Kooperatifleri, Tarım Satış Kooperatifleri, Tarımsal Kalkınma Kooperatifleri, Sulama Kooperatifleri ve $\mathrm{Su}$ Ürünleri Kooperatifleri) ve diğer tarımsal organizasyonlar (Sulama Birlikleri, Köylere Hizmet Götürme Birlikleri) olmak üzere üç grupta incelemek mümkündür.

Çalışma alanımızda 45'i ekonomik amaçlı kooperatif, 9'u mesleki örgüt ve 32'si de diğer organizasyonlar olmak üzere toplam 85 üretici örgütü bulunmaktadır (Çizelge 9). Şanlıurfa ilinin kırsalında kurulu olan tarımsal kalkınma amaçlı kooperatifler, daha çok kuzeydeki plato alanlarında, özellikle de Siverek-Viranşehir Platosu'nda bir dağılış göstermektedirler (Şekil 8). Siverek-Viranşehir Platosu'nda kurulan ve faaliyet gösteren söz konusu kooperatiflerin büyük bir kısmı, hayvancılık faaliyetlerine yönelik faaliyet göstermektedirler. İlde tarım sektöründe kooperatifleşme düzeyi, hem kuru koşulların, hem de sulu koşulların hakim olduğu alanlarda oldukça düşüktür.

Bölge ve ülke genelinde üretici örgütlerin durumu ise, üretici örgütlerin sayısı GAP'ta 430'a ve Türkiye'de ise 12244'e çıkmaktadır. Şanlıurfa ilindeki üretici örgütlerinin GAP ve Türkiye içindeki payları incelendiğinde, GAP içindeki payı \% 19.5, Türkiye'deki payı ise \% 0,7'dir. Ancak, tarım üreticileri için büyük bir öneme sahip olan ekonomik amaçlı üretici örgütler değerlendirildiğinde ise, Şanlıurfa ilinin (44), GAP içindeki payı \% 15,3'e (287) ve Türkiye'deki payı da \% 0,4'e (11348) düşmektedir (Çizelge 9). Oysaki, Şanlıurfa ili, Çizelge 1'de de görüldüğü gibi, GAP Bölgesi'ndeki tarım alanlarının \% 36,2'sını ve Türkiye'deki tarım alanlarının ise \% 4,2'sını kaplamaktadır. Dolayısıyla tarım üreticilerinin ekonomik amaçlı üretici örgütleri konusunda gerek GAP'a ve gerekse Türkiye’ye göre daha fazla örgütlenmeleri gerekirken, aksi bir durum söz konusudur. 
Cizelge 9. Sanlıurfa ilinde, GAP'ta ve Türkiye'de üretici örgütleri ve üye sayıs1*

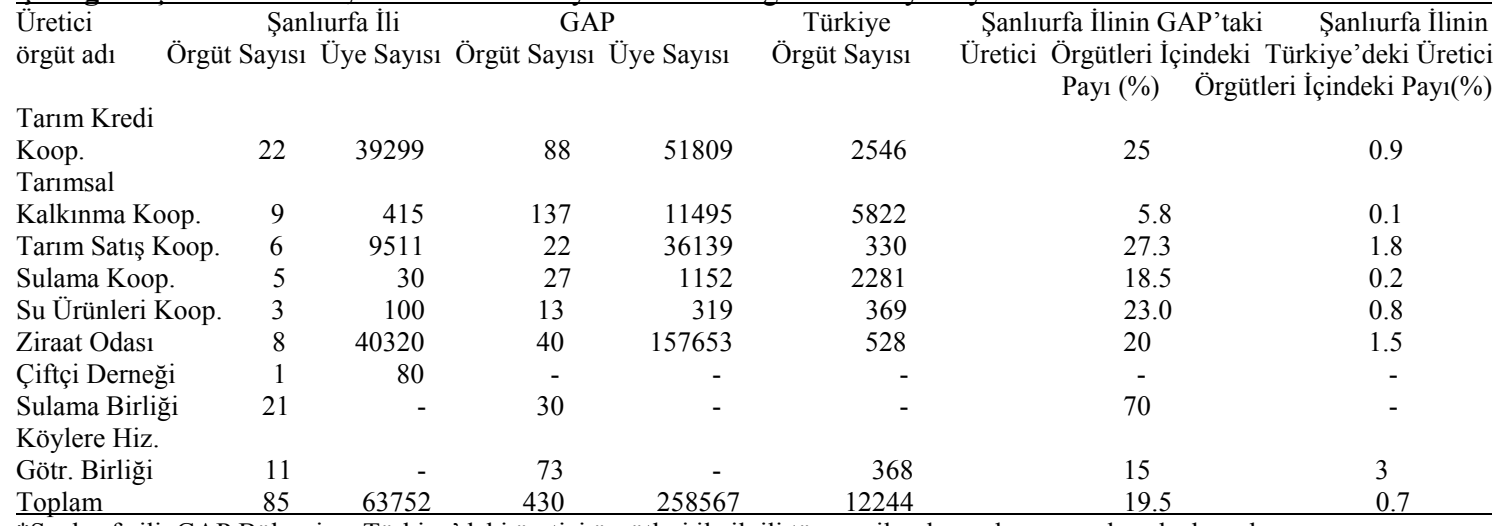

*Şanlıurfa ili, GAP Bölgesi ve Türkiye'deki üretici örgütleri ile ilgili tüm veriler, kamu kurum ve kuruluşlarından ve

diğer çalışmalardan derlenerek araştırıcı tarafından düzenlenmiştir.

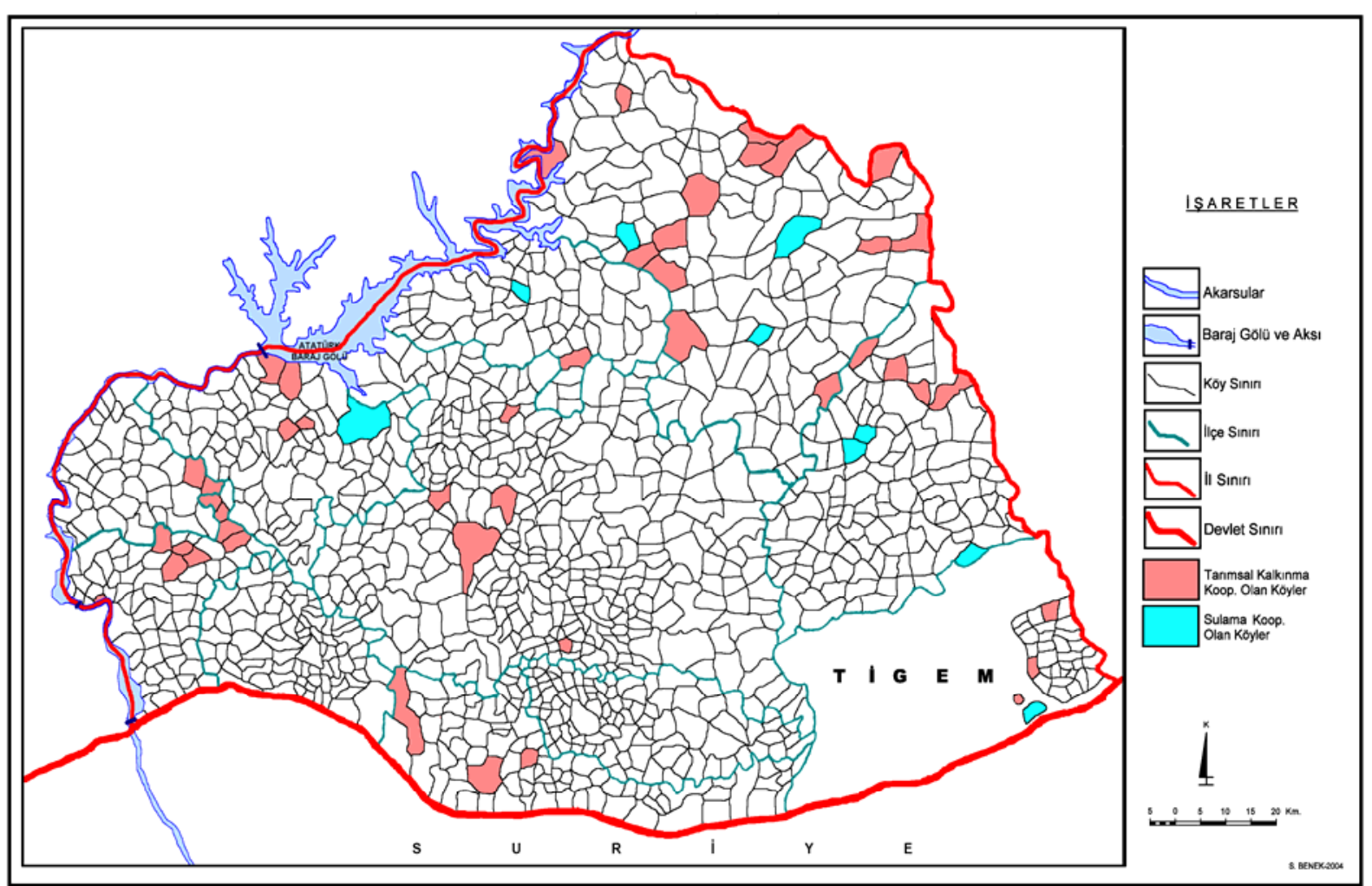

Şekil 8. Şanlıurfa ilinde tarımsal amaçlı kooperatifi olan köylerin dağılışı (2004)

Tarımsal faaliyetlerin gelişmesinde önemli görevleri olan Tarım Kredi Kooperatifleri ile Tarım Satış Kooperatiflerinin ilçeler bazında örgütlenme durumlarını incelemek ayrı bir önem taşımaktadır. Tarım Kredi Kooperatiflerinin amacı; ortaklarının her türlü tarımsal girdi ihtiyaçlarını uygun fiyatla temin etmek ve dağıtmak, ortaklarına kısa, orta ve uzun vadeli tarımsal kredileri ayni ve nakdi olarak kullandırmaktır. Bu kapsamda çalışma alanımızda 22 Tarım Kredi Kooperatifi bulunmaktadır. Diğer tarafta, Şanlıurfa ilinde toplam Tarım Satış Kooperatifinin 3'ü Merkez ilçede, 1'rer adet de Akçakale, Birecik ve Suruç ilçelerinde olmak üzere toplam 6'dır. Çalışma alanımızda 4'ü Siverek, 3'ü Akçakale, 1'er adet de Merkez ve Bozova ilçelerinde olmak üzere toplam 9 adet Tarımsal Kalkınma Kooperatifi bulunmaktadır. Tarımsal Kalkınma Kooperatiflerinin kuruluş amacına 
bakıldığında, çok amaçlı kooperatifler olup, daha çok ortaklarının girdi ihtiyaçlarını karşılayan ve ürünlerini değerlendirerek pazarlamasını sağlayan kooperatiflerdir. Tarım Satış Kooperatiflerinin kuruluş amacı, faaliyet konusuna giren tarım ürünlerini üreticilerden satın almak, işlemek, standart hale getirmek ve ambalajlayarak iç ve dış pazarlarda pazarlamak ve gerektiğinde üreticilerin tarımsal girdilerini karşılamaktır. Ayrıca, çalışma alanımızda 415 ortak sayısı ile 9 adet tarımsal kalkınma amaçlı kooperatif, 138 ortak sayısı ile de 7 sulama amaçlı kooperatif de mevcuttur (Çizelge 10).

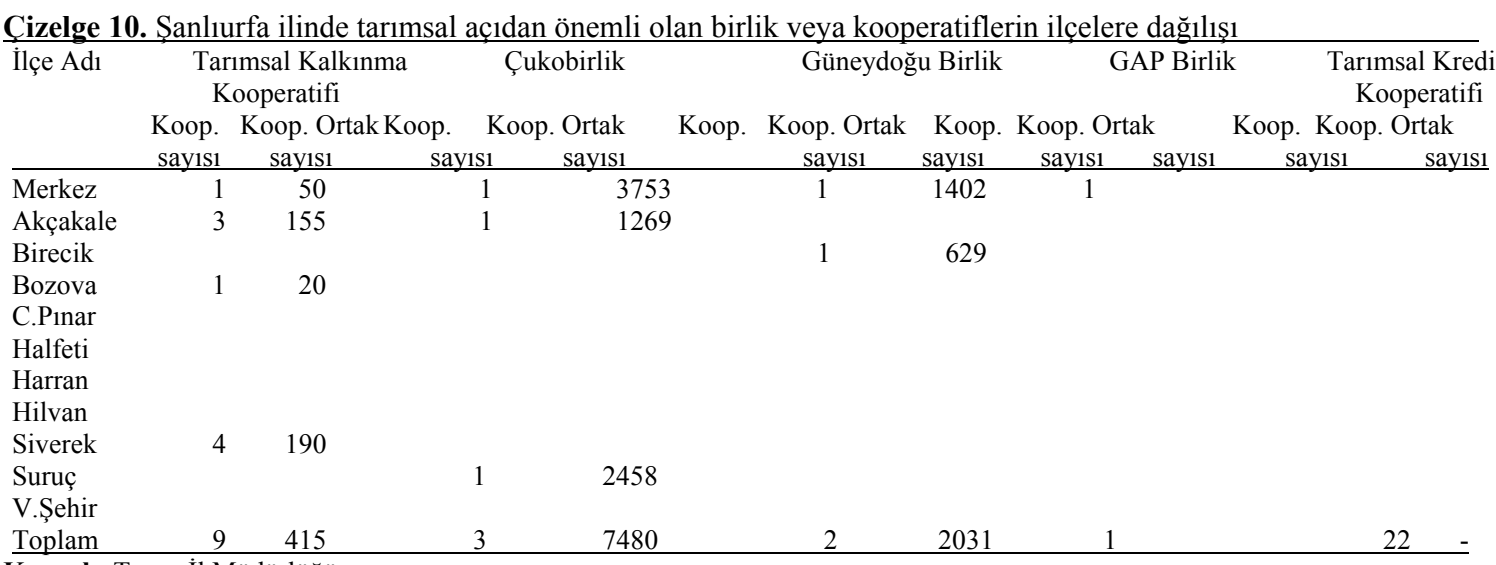

Kaynak: Tarım İl Müdürlüğü

Çalışma alanımızdaki çiftçilerin büyük bir bölümünün örgütlenememesinin nedenlerinden birisi de, eğitim seviyesinin düşüklüğüdür. Bu nedenle kendilerine aktarılan bilgileri algılayamamakta, tarımı bilgi ve becerilerine göre yapmaktadırlar. Ayrıca, bir kısım çiftçiler (topraksız ve az köylüler) ise tarla sahibi olmadıklarından çiftliklerine geçici gözüyle bakmakta, teknik koşulları göz ardı etmektedirler.

Çalışma alanımızda üretici örgütlerden en aktif olan örgütlerden birisi de sulama birlikleridir. Sulama alanlarının artmasıyla birlikte, 2004 yılı itibarı ile, kamu tarafından sulamaya açılan yaklaşık 138.729 ha'llk alanda 21 adet sulama birliği kurulmuştur (Şekil 9). Bu sulama birliklerine, sulama şebekesinin büyük yedek kanallar haricinde işletilmesi ve bakımı devredilmiştir. Bu bir anlamda çiftçinin örgütlenmesi ve kendi kendini yönetmesidir. Bir çiftçinin sulama birliklerine üye olabilmesi için sulama kapsamına giren alanlarda (köy ve mahalle) mülk sahibi olması gerekmektedir. Ancak, sahada yaptığımız gözlemlerde pamuk tarımı ile uğraşan bir kısım çiftçi, kiracı, ortakçı veya sucu konumunda olup, arazi sahibi olmadığından dolayı sulamada hassas davranmamaktadırlar. Bu duruma karşın, arazi sahiplerinin bir kısmı ise, şehirde yaşamasına rağmen birliğe üye olabilmekte ve hatta çoğu zaman birlik başkanı bile olabilmektedirler. Bu çarpık durumun giderilmesi veya en aza indirgenmesi için ilgili kurumlarca çalışmalar yapılmalıdır. 


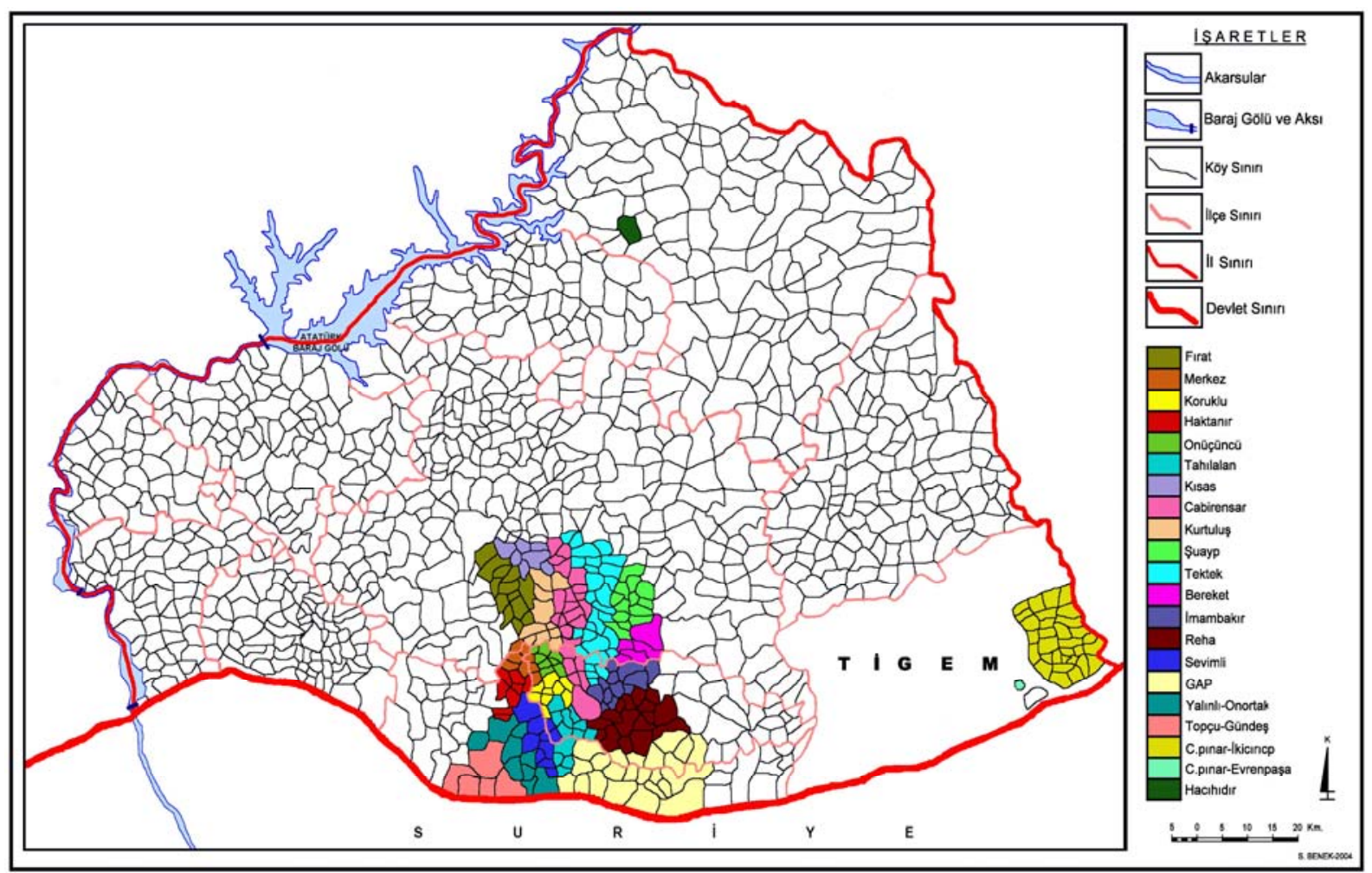

Şekil 9. Şanlıurfa ilinde sulama birliklerinin dağıllışı (2004)

\section{Makineleșme}

GAP süreci ile birlikte çalışma alanımızda, makineleşme konusunda ciddi gelişmeler gözlenmesine rağmen halen yeterli düzeyde olduğu söylenemez. Tarımsal mekanizasyon düzeyinin yükselebilmesi için sulama projelerinin bir an önce tamamlanarak faaliyete geçmesi gerekmektedir. Çünkü sulu koşullarda yapılan tarımsal faaliyetler sonucunda üretim ve verim arttığından dolayı artı değer de artmaktadır. Bu da üreticilerin tarımda kullandıkları girdi düzeyini ve yatırım miktarını olumlu yönde etkilemektedir. KHGM tarafindan 1981 yılında yapılan Köy Envanteri Etüdü çalışmasına göre Şanlıurfa ilinde her köye ortalama 5 traktör düşerken, 1997 yılında DİE tarafindan yapılan Köy Envanteri çalışmasında ise her köye ortalama 10 traktör düşmektedir (Çizelge 11). Bu durum, bize, çalışma alanımızda GAP süreci ile birlikte tarımsal mekanizasyon içersinde önemli bir faktör olan traktör sayısında önemli bir artış olduğunu göstermektedir.

Çizelge 11. Șanlıurfa ilinde ilçeler bazında traktör sayısı ve her köye düșen ortalama traktör sayıs

\begin{tabular}{|c|c|c|c|c|c|c|}
\hline İlçeler & $\begin{array}{l}\text { Köy } \\
\text { say1sı }\end{array}$ & $\begin{array}{l}\text { Traktör } \\
\text { sayısı }\end{array}$ & $\begin{array}{l}\text { 1981* } \\
\text { Her köye } \\
\text { düşen traktör } \\
\text { sayısı }\end{array}$ & $\begin{array}{l}\text { 1997** } \\
\text { Köy } \\
\text { say1s1 }\end{array}$ & $\begin{array}{l}\text { Traktör } \\
\text { sayısı }\end{array}$ & $\begin{array}{l}\text { Her köye } \\
\text { düşen traktör } \\
\text { sayısı }\end{array}$ \\
\hline Merkez & 185 & 809 & 4 & 296 & 2795 & 9 \\
\hline Akçakale & 117 & 331 & 3 & 83 & 768 & 9 \\
\hline Birecik & 39 & 268 & 7 & 69 & 901 & 13 \\
\hline Bozova & 77 & 293 & 4 & 77 & 821 & 11 \\
\hline Ceylanpınar & - & - & - & 32 & 425 & 13 \\
\hline Halfeti & 33 & 68 & 2 & 37 & 295 & 8 \\
\hline Harran & - & & - & 84 & 687 & 8 \\
\hline Hilvan & 55 & 341 & 6 & 56 & 729 & 13 \\
\hline Siverek & 65 & 399 & 6 & 111 & 1246 & 11 \\
\hline Suruç & 73 & 244 & 3 & 80 & 512 & 6 \\
\hline Viranşheir & 45 & 352 & 8 & 104 & 904 & 9 \\
\hline Toplam & 689 & 3105 & 5 & 1029 & 10083 & 10 \\
\hline
\end{tabular}

Kaynak: KHGM Köy Envanter Etüdü* - DİE 1997 Köy Envanteri** 
GAP İdaresi (1996 yılında) tarafından artan sulamalı tarım koşullarının oranına bağlı olarak GAP illerinde ihtiyaç duyulacak mekanizasyon düzeyi ile ilgili teknik bir analiz araştırması yapılmıştır. Bu teknik analiz araştırması sonucunda, Şanlıurfa ilinde sulamaya açılacak tarım miktarının değişkenine bağlı olarak toplam tarım alanlarının \% 20'sinin sulamaya açılması durumunda 8819 traktör, 1204 kulaklı pulluk, 1725 kültivatör, 3399 tarım arabası ve 962 çapa makinesine ihtiyaç duyulacağı tahmin edilmiştir. Bu bağlamda çalışma alanımızda sulamalı tarım alanlarının oranının \% 50'ye çıkması durumunda, 30931 traktöre, 12554 kulaklı pulluğa, 1542 kültivatöre, 3467 tarım arabasına ve 2565 çapa makinesine ihtiyaç duyulacaktır (Çizelge 12). Burada en çok dikkat çeken nokta, çalışma alanımızda tarım alanlarının \% 50'sinin sulamaya açılması durumunda, traktör sayısından 3,5 katlık bir artışla 8819 traktörden 30931 traktöre ihtiyacının olacağı senaryosudur. Çalışma alanımızda sulamalı tarım oranına bağlı olarak yapılan bu mekanizasyon teknik analizinden hareket edilerek, 2004 yılı itibariyle, tarım alanlarının (1.200.573 ha) kamu ve özel halk sulamaları olmak üzere yaklaşık \% 30'u sulamalı tarıma açılmıştır. Bu dönemde çalışma alanımızda söz konusu tarımsal araç-gereçlerinin sayısına bakıldığında, 12515 traktör, 8554 kulaklı pulluk, 9913 kültivatör, 9858 tarım arabası, 1847 çapa makinesi bulunmaktadır (DİE, 2002: 510). Sulu tarım alanlarının oranına bağlı olarak tarımsal araç-gereç ihtiyaç durumuna ilişkin oluşturulan bu senaryolar ile 2004 yılı itibariyle gerçekleşen sulama alanları ile araç-gereç sayısı bakımından karşılaştırıldığında, traktörde çok düşük bir seviyede makineleşme düzeyinin gerçekleşmekte olduğu, diğer tarımsal araçgereçlerde ise beklentilerin de üzerinde bir hızla gerçekleşmekte olduğu görülmektedir.

Cizelge 12. Sanliurfa ilinde bazı tarımsal araç-gereçerde

\begin{tabular}{lccc}
\multicolumn{3}{l}{ sulu-kuru koșullarda ihtiyaç durumuna ilișkin senaryolar } & \\
\cline { 1 - 3 } Tarım Araç- & \% 80 Kuru & \% 50 Kuru & \% 30 Kuru \\
Gereç İhtiyac1 & \% 20 Sulu & \% 50 Sulu & \% 70 Sulu \\
\hline Traktör & 8819 & 30931 & 39660 \\
Kulaklı Pulluk & 12042 & 12554 & 16303 \\
Kültivatör & 1725 & 1542 & 1822 \\
Tarım Arabası & 3399 & 3467 & 4373 \\
Capa Makinesi & 962 & 2565 & 2889 \\
\hline
\end{tabular}

Kaynak: GAP-BKİ, GAP Bölgesinde Tarımsal Mekanizasyon

Gereksinimleri Etüdü Projesi, 1996.

Ancak tüm bu gelişmelere rağmen GAP alanındaki (ve dolayıyla Şanlıurfa ilinde) mekanizasyon düzeyi Türkiye ortalamasının altındadır. 2003 yılı itibariyle, Türkiye'de bir traktöre 28,9 hektar arazi düşerken, GAP Bölgesi'nde 67,3 hektar ve Şanlıurfa ilinde ise 95,2 hektar arazi düşmektedir.

GAP süreci ile birlikte Şanlıurfa ilinde tarımda mekanizasyon düzeyi önemli bir gelişme göstermiş̧ir. Ancak, bu gelişme düzeyi, yukarıda da belirtildiği gibi, modern tarım koşullarında olması gereken bir düzey değildir. Çünkü, çalışma alanımızda makineleşme düzeyi, halen Türkiye ortalamasının altında kalmaktadır. Burada dikkat çeken iki önemli nokta vardır. Birincisi, GAP ile birlikte Şanlıurfa ilinde ciddi anlamda bir makineleşme sürecinin yaşandığı, ikincisi ise, sulamada kullanılan tarımsal araç-gereçlerde artış oranının daha fazla olduğudur. Bu her iki maddenin en fazla gelişme gösterdiği ilçeleri, daha çok sulama alanları artan ilçeler oluşturmaktadır (Şekil 10, 11, 12). 


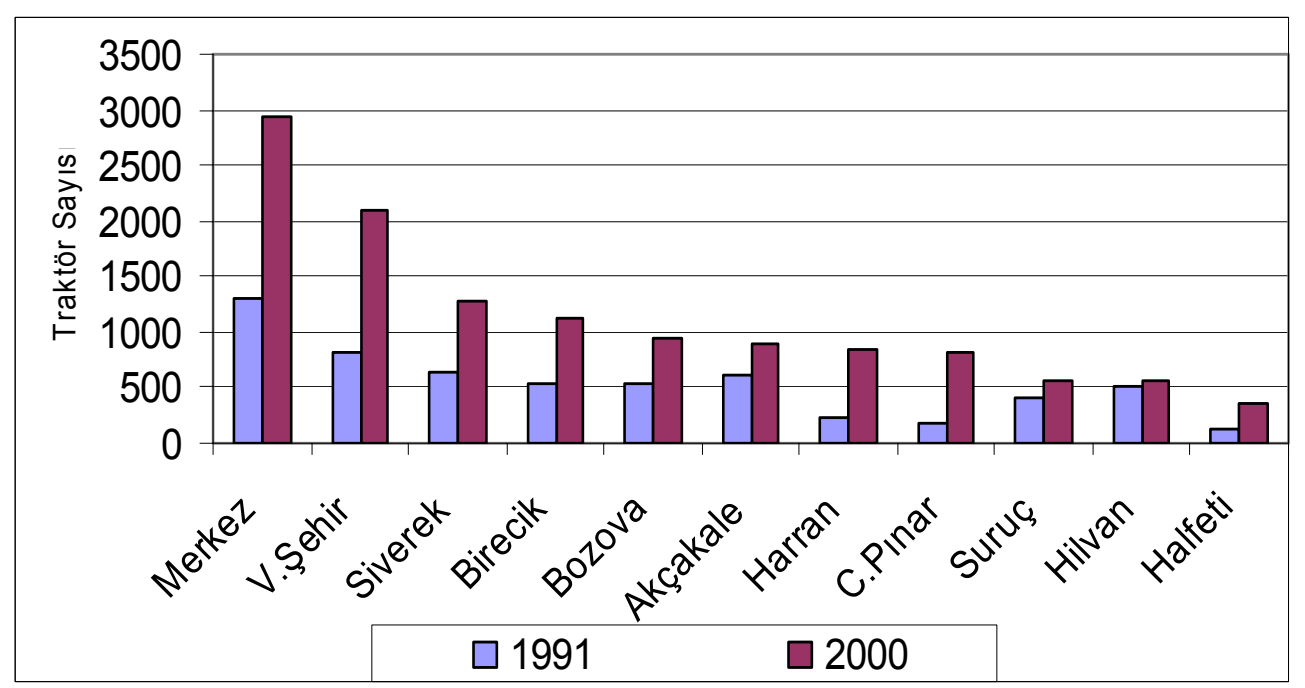

Şekil 10. Şanlıurfa ilinde ilçeler bazında traktör sayısındaki gelişmeler (1991-2000)

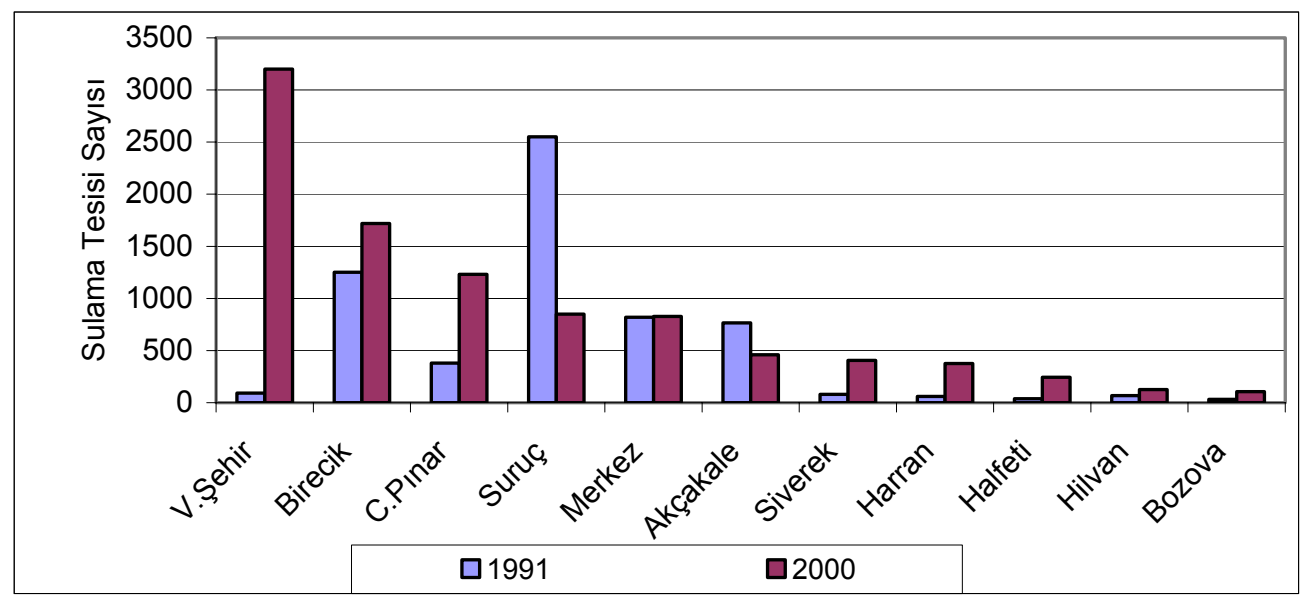

Şekil 11. Şanlıurfa ilinde ilçeler bazında sulama tesisi sayısındaki gelişmeler (1991-2000)

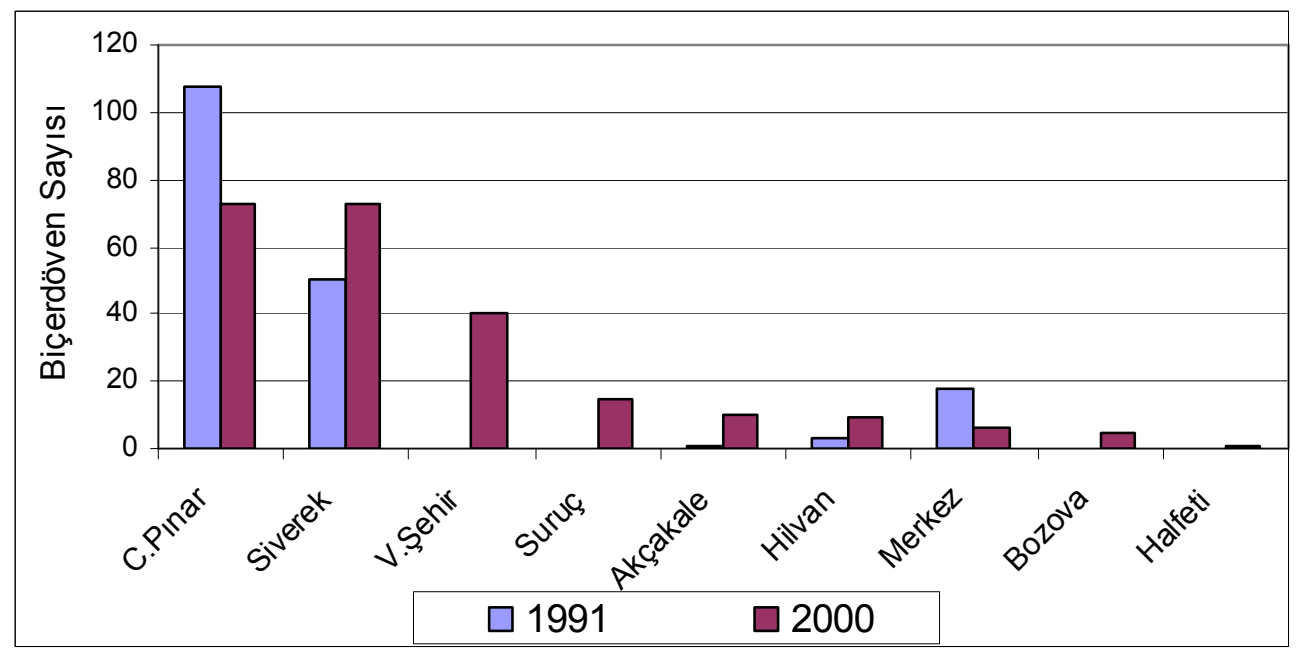

Şekil 12: Şanlıurfa ilinde ilçeler bazında biçer döven sayısındaki gelişmeler (1991-2000) 


\section{Tohum Kullanımı}

Tarımın yapısal sorunlarından birisi de yeterli miktarda ve kalitede tohum kullanılmamas durumudur. Bu konuda yapılan araştırmalarda, ekimde kullanılan tohumun kalitesinin üretilen ürünün verimi üzerinde, kalitesinde ve hatta pazarlamasında etkili olduğu saptanmıştır. Bu boyutu ile olaya bakıldığında, çiftçilerin büyük bir çoğunluğu bilimsel metotlarla değil, yıllarca edindikleri geleneksel birikimleri doğrultusunda tohum kullanmaktadırlar.

Yapılan araştırmalara göre, tarımsal üretimde, gübreleme, sulama ve ilaçlama gibi yetiştiricilik tekniklerinin zamanında ve doğru uygulanmasının verime etkisi çok fazladır. Bunun yanında tarımsal üretimde sertifikalı tohumluk kullanımı; genetik vasfının sağladığı yararlara ilave olarak bitki çeşidine göre değişmekle birlikte, kendine döllenen buğday, arpa ve yem bitkilerinde \% 20-25'e, hibritlerde ise $\%$ 100'e varan verim ve kalite artışı sağlamaktadır (TİGEM, 2003: 1).

Tarım İl Müdürlügü̈’nün verilerine göre, 2003 yılı itibariyle Şanlıurfa ilinde satış amaçlı faaliyet gösteren 8 adet ruhsatlı tohum bayisi bulunmaktadır. İlde bir kamu kuruluşu olan Ceylanpınar TİGEM dışında tohum yetiştiriciliği yapan kişi ve kuruluş mevcut değildir. Yapılan hesaplara göre TIGGEM'ce üretilen tohumluklar ilin ihtiyacını karşılamaktan uzaktır. Burada üretilen buğday, arpa, mercimek, pamuk ve fiğ tohumlukları, ilçe müdürlükleri tarafından üreticilere ulaştırılmaktadır. Sahada yaptığımı gözlem ve görüşmelerde çiftçilerin büyük bir kısmının sertifikalı tohum kullanmadıkları gözlenmiştir. Ancak, meyve dikimi için son zamanlarda çok sayıda fidan üretim işletmesi kurulmuştur. Bu fidan üretim işletmelerinde daha çok antepfistığı, badem, üzüm asması, ceviz, erik, şeftali, kiraz, nar, incir vb. üretilmektedir. Sulama alanları artıkça fidan talebi artmakta ve böylece dikili tarım alanları da artmaktadır. Antepfıstığı, üzüm asması, incir ve badem meyvelerinin halen büyük bir kısmı kuru koşullarda üretilmekte, diğer meyvelerde ise daha çok sulu koşullarda üretimi tercih edilmektedir.

Tarım il Müdürlüğü'nün tahminlerine göre, Şanlıurfa ilinde, yaklaşık olarak 79000 ton buğday, 39150 ton arpa, 17030 ton kırmızı mercimek, 8966 ton pamuk çiğiti, 450 ton nohut, 206 ton susam ve 91 ton ikinci ürün olarak mısır kullanılmaktadır (TKB, 2002: 12).

Çalışma alanımızda sulu tarım alanlarının artmasının paralelinde pamuk ekim alanları da artmaktadır. Bu bağlamda pamuk yetiştiriciliğinin önde gelen sorunlarından biri de şüphesiz yetişebilecek çeşitlerin yüksek verimli, teknolojik özellikleri yeterli ve hastalıklara dayanıklı olmalıdır. Daha önceleri Harran Ovası'nda geniş sahalarda ekilen ve teknolojik özellikleri yetersiz olan Aleppo-I (Halep) çeşidini Çukobirlik 1990 yılından itibaren almaya başlamıştır. Genellikle çiftçiler o güne kadar Aleppo-I çeşitlerine rağbet etmişler ve hiç bir kontrole tabi olmayan piyasadan buldukları tohumları ekerek pamuk yetiştiriciliğine devam etmişlerdir. Köy Hizmetleri Şanlıurfa Araştırma Enstitüsü'nün kuruluşundan günümüze kadar devam eden pamuk denemelerinden elde edilen bulgulara göre Sayar 314 ve Mc Nair çeşitlerinin başta Harran Ovası olmak üzere bölgede çok iyi uyum sağladığı görülmüştür (GAP-BKİ, 1996: 35).

Ayrıca, önümüzdeki yıllarda sulu tarımın ve pamuk yetiştiricilerinin yaygınlaşmasıyla bazı hastalık ve zararlılar daha fazla yayılacak ve daha fazla zarara yol açabilecektir. Bunun için de bu konuda şimdiden önlem almak gerektiği düşüncesiyle daha önce yürütülen çalışmalarda verim ve teknolojik özellikler yönünden üstün olan sayar 314 ve Mc Nair 235 çeşitleri, çiftçilere önerilmektedir. Ancak, bu iki tohum çeşidinin aşırı sulamada solgunluk hastalığına karşı hassas oldukları saptanmıştır. $\mathrm{Bu}$ durumda, Kahramanmaraş Tarla Bitkileri Üretme İstasyonu'nda solgunluk hastalığına karş1 dayanıklı olduğu belirlenen ve yapılan çalışmalarda da Şanlıurfa iline iyi uyum gösteren Kahramanmaraş 92 ve Erşan 92 çeşitleri de çiftçilere önerilmektedir (Ferhatoğlu ve Anlağan, 1996: 22).

Çalışma alanımızda başta pamuk olmak üzere ekilen ürünlerin tohumu ile ilgili önemli bir nokta da, ekilecek tohumun nasıl elde edilmekte olduğudur. Bu konu üzerinde gerekli önlemlerin alınması ve belli kuruluşların bu konuda görevler üstlenmeleri gerekmektedir. Kaynağı belli olmayan karışık çiğitlerin ekilmesiyle elde edilen ürünün kütlü kalitesinin iyi olmayacağı açıktır. Ayrıca bunların çimlenme ve çıkış oranlarının ve verim durumlarının ne olacağı bilinmemektedir. 


\section{Gübreleme}

Gübreleme, bitkisel üretimde amaçlanan verim ve kaliteye ulaşmak için içerisinde bir veya birkaç çeşit bitki besin maddesi bulunan, organik veya inorganik bileşiklerin, toprağa veya doğrudan doğruya bitkiye verilmesi şeklinde tarif edilmektedir (Özer, 1999: 22). Devamlı ziraat yapılan topraklarda elementer besin maddeleri bir yandan bitkilerin tüketimi, öte yandan sulama suyu ile yıkanması sonucu zamanla azalır. Ayrıca, Aerop bakterilerinin humusu parçalamaları da toprağın organik madde dengesinin bozulmasına ve azot bakımından fakirleşmesine sebep olur (Aydemir, 1982: 260-261). Bu nedenle tarımda gübrelemenin zamanında ve yeterli miktarda kullanılmas1 gereklidir.

Gübre kullanımı konusunda, çalışma alanımızla ilgili olarak gerek yapılan bilimsel çalışmalarda gerekse sahadaki gözlemlerimiz sonucunda temel sorunlar olarak kullanılan gübre miktarının düşük olması, gübrenin toprağın özelliklerine bakılmaksızın kullanılması, yetiştirilen bitkiye uygun gübre/gübrelere dikkat edilmemesi ve zamanında kullanılmaması gibi problemler öne çıkmaktadır. Çünkü asırlardır kuru tarım koşullarında tarımla uğraşan yöre çiftçiler için sulu koşullarda modern tarım yöntemleriyle bitki yetiştiriciliği yapmak oldukça zor ve zaman alan bir durumdur.

Türkiye ortalaması olarak gübrelenen arazide $50 \mathrm{~kg} / \mathrm{da}$ gübre tüketimine karşıllk, bu miktar Harran Ovas1 için ortalama $18.7 \mathrm{~kg} / \mathrm{da}$ olarak hesaplanmıştır. Yörede yetiştirilmekte olan ürün çeşitlerinde suni gübre kullanımı ise, hububatta $13.8 \mathrm{~kg} / \mathrm{da}$, pamukta $39.3 \mathrm{~kg} / \mathrm{da}$, mercimekte $10 \mathrm{~kg} / \mathrm{da}$ olarak bulunmuş olup, ortalama gübre tüketim değerinin çok altında kalmaktadır (Aksoy ve Arkadaşları, 1986: 54). Bölgede gübre kullanımına ilişkin bu veriler, GAP öncesi döneme ait olup, suni gübre kullanımının düşük bir seviyede olduğunu göstermektedir. Ancak, GAP süreci ile birlikte tarım girdilerinde kısmen de olsa ekonomik durumun iyileşmesine bağlı olarak ciddi değişmeler yaşanmaktadır. $\mathrm{Bu}$ dönem içerisinde, çalışma alanımızda gerek kullanılan gübre miktarı ve gerekse birim alanda kullanılan gübre miktarında artışlar olmuştur. Çalışma alanımızda 1987 yılında toplam 301128 ton kimyevi gübre kullanılırken, 2002 yılına gelindiğinde bu rakam \% 71,2'lik bir artışla 423044 tona yükselmiştir (Çizelge 13). Böylece genel olarak kullanılan gübre miktarının artışına bağlı olarak birim alanda kullanım düzeyi de artmıştır. Çalışma alanımızda, GAP öncesinde (1987 yılında) dekara $18.7 \mathrm{~kg}$. kullanılırken, GAP süreci (2002 yılında) ile birlikte dekara atılan gübre miktarı artarak $35.5 \mathrm{~kg} / \mathrm{da}$ 'a ulaşmışıı (Çizelge 14).

\begin{tabular}{|c|c|c|c|c|c|}
\hline \multirow[t]{2}{*}{ Yillar } & \multicolumn{2}{|c|}{ Azotlu (\% 21) } & \multicolumn{3}{|c|}{ Fosforlu (\% 16-18) } \\
\hline & Ton & $\%$ & Ton & $\%$ & Ton \\
\hline 1987 & 161555 & 53,6 & 139573 & 46,4 & 301128 \\
\hline 1990 & 146750 & 61,9 & 90393 & 38,1 & 237143 \\
\hline 1995 & 122100 & 52,9 & 108836 & 47,1 & 230936 \\
\hline 1997 & 136704 & 56,2 & 106447 & 43,8 & 243151 \\
\hline 1999 & 301175 & 65,9 & 155952 & 34,1 & 457127 \\
\hline 2002 & 282935 & 66,9 & 140046 & 33,1 & 423044 \\
\hline
\end{tabular}

Kaynak: TÜİK.

Çizelge 14. Birim tarım alanında gübre kullanımın oransal gelişimi

\begin{tabular}{lccc} 
Yillar & Azotlu(kg/da) & Fosforlu (kg/da) & Toplam $(\mathrm{kg} / \mathrm{da})$ \\
1987 & 13,43 & 11,60 & 25,03 \\
1990 & 12,19 & 7,51 & 19,70 \\
1995 & 10,15 & 9,04 & 19,19 \\
1997 & 11,36 & 8,84 & 20,20 \\
1998 & 18,85 & 15,18 & 34,03 \\
1999 & 25,03 & 12,96 & 37,99 \\
2002 & 23,7 & 11,8 & 35,5 \\
\hline
\end{tabular}

Kaynak: TÜİK

Şanlıurfa ilinde, 2002 yılı itibariyle, kullanılan suni gübre miktarı (423044 ton), Türkiye'de kullanılan gübrenin (8645641 ton) \% 4,9'una, GAP Bölgesi'nde kullanılan gübrenin (1072954 ton) ise 
\% 39,4'üne tekabül etmektedir (Çizelge 15). Birim alanda kullanılan ortalama gübre miktarı değerlendirildiğinde, Şanlıurfa ili $(35,5 \mathrm{~kg} / \mathrm{da})$, Türkiye ortalamasının $(42,4 \mathrm{~kg} / \mathrm{da})$ altında, GAP Bölgesi'nin (32,6 kg/da) ise üstünde bir seviyededir (Çizelge 16).

\begin{tabular}{|c|c|c|c|c|c|c|c|c|}
\hline \multirow[t]{2}{*}{ Yerleşim Birimi } & \multicolumn{2}{|c|}{$\begin{array}{l}\text { Azotlu } \\
\text { (\% 21) }\end{array}$} & \multicolumn{2}{|c|}{$\begin{array}{c}\text { Fosforlu } \\
(\% 16-18)\end{array}$} & \multicolumn{2}{|c|}{$\begin{array}{l}\text { Potasli } \\
\text { (48-52) }\end{array}$} & \multicolumn{2}{|c|}{ Toplam } \\
\hline & Ton & $\%$ & Ton & $\%$ & Ton & $\%$ & Ton & $\%$ \\
\hline Türkiye & 5708835 & 66,0 & 2789670 & 32,3 & 141136 & 1,6 & 8645641 & \\
\hline GAP & 727275 & 67,8 & 341000 & 31,8 & 1023 & 0,1 & 1072954 & \\
\hline $\begin{array}{l}\text { Şanllurfa } \\
\text { Şanllurfa İlinin } \\
\text { Türkive İcindeki }\end{array}$ & 282935 & 66,9 & 140046 & 33,1 & 63 & & 423044 & \\
\hline $\begin{array}{l}\text { Payl(\%) } \\
\text { Şanlıurfa İlinin } \\
\text { GAP İçindeki }\end{array}$ & 5,0 & - & 5,0 & - & - & & 4,2 & 4,9 \\
\hline Pay1 $(\%)$ & 38,9 & - & 41,1 & - & 6,2 & & 37,2 & 39,4 \\
\hline
\end{tabular}

Kaynak: DİE, Tarımsal Yapı.

Cizelge 16. Birim tarım alanına gübre kullanımı (2002)

\begin{tabular}{|c|c|c|c|c|}
\hline Yerleșim Birimi & Azotlu (kg/da) & Fosforlu (kg/da) & Potasl1 $(\mathrm{kg} / \mathrm{da})$ & Toplam (kg/da) \\
\hline Türkiye & 28,0 & 13,7 & 0,7 & 42,4 \\
\hline GAP & 22,1 & 10,4 & - & 32,6 \\
\hline Șanliurfa & 23,7 & 11,8 & - & 35,5 \\
\hline
\end{tabular}

Kaynak: DİE, Tarımsal Yapı, 2002.

Kimyasal gübre çeşitleri içerisinde özellikle nitrat ve sülfatlı gübrelerin kullanımında dikkatli davranılmaması durumunda, toprakta $\mathrm{PH}$ derecesinin yükselmesi durumu ortaya çıkmaktadır. PH derecesi yükselen topraklarda ise, alkalileşme artmaktadır. Böylece mevzi ölçeklerde toprak yapısı ile iklim özellikleri açısından çoraklaşmaya müsait olan yöre toprakları, yanlış arazi kullanımı sonucunda çoraklaşma tehlikesiyle karşı karşıyadır.

\section{Tarımsal İlaç Kullanımı}

Tarımsal üretimi ve verimi etkileyen bir diğer faktör ise, zamanında, uygun ve yeterli miktarda tarımsal ilaç kullanımıdır. Çalışma alanımızda, tarımsal ilaç kullanımında da, gübre kullanımında karşılaşılan problemlere benzer problemler yaşanmaktadır. Yöre çiftçileri, tarımsal bitkilerle ilgili olarak ortaya çıkan hastalıkların tanımlanması ve buna göre tarımsal ilaç çeşidinin kullanımı konusunda, uzmanlara başvurmadan, gelişigüzel kullanmaktadırlar. Sulamalı tarımla birlikte tarımsal hastalıkların sayısı ve etkisi de artmaktadır. Bu nedenle, yöre çiftçilerini sadece gübre ve tarımsal ilaç kullanımı konusunda teşvik etmek veya bilinçlendirmek yeterli değildir. Aynı zamanda bitkisel hastalıkların tespiti ve buna göre tarımsal ilacın seçimi, miktarı ve kullanım zamanı ile ilgili olarak da konunun uzmanlarına başvurulması gerektiği yönünde bilinçlendirilmeleri gerekmektedir.

Şanlıurfa ilinde tarımsal üretimde ilaç kullanımı iklim koşullarına, hastalık ve zararlılara, ürün desenine, tarımsal ilaç fiyatlarına ve çiftçinin alım gücüne bağlı olarak değişmektedir. Özellikle, ilaçların bileşimi ve etkili madde oranı ile iklim koşulları etkili olmaktadır. İlde en çok kullanılan ilaç grupları insektisit, füngusit, herbisit, akarisit ve yazlık ve kışlık yağlardır. Bütün bu ilaç gruplarının toplam ilaç kullanımındaki payları yıllar itibariyle dalgalanma göstermektedir. İlde 38 adet ilaç bayisi faaliyette olup, 2000 yılı itibariyle $180.753 \mathrm{~kg}$. ilaç kullanılmıştır (TKB, 2002: 173). Çalışma alanımızda, 2003 yılı itibariyle, Şanlıurfa Tarım İl Müdürlüğünün verilerine göre 35'i merkez ilçede olmak üzere toplam 85 zirai ilaç bayisi bulunmaktadır (Çizelge 17).

Cizelge 17. Şanlıurfa ilinin tarımında halk sağlığı ve zirai mücadele bayilerinin ilçelere dağılıșı

\begin{tabular}{|c|c|c|c|c|c|c|c|c|c|c|c|c|}
\hline \multirow{2}{*}{ Bayii türü } & \multicolumn{12}{|c|}{ İlçeler } \\
\hline & Merkez & Akçakale & Birecik & Bozova & C.Pınar & Halfeti & Harran & Hilvan & Siverek & Suruç & V.Şehir & Toplam \\
\hline Halk Sağlığ & 13 & & & 1 & 1 & & 1 & 1 & 1 & & 1 & 19 \\
\hline Zirai Mücadele & 35 & 1 & 7 & 4 & 3 & 1 & 1 & 5 & 9 & 5 & 14 & 85 \\
\hline Toplam & 48 & 1 & 7 & 5 & 4 & 1 & 2 & 6 & 10 & 5 & 15 & 104 \\
\hline
\end{tabular}

Kaynak: Tarım İl Müdürlüğ̈̈, 2003. 
Çalışma alanımız ve yakın çevresinde yapılan bilimsel araştırmalar sonucunda, bölge topraklarının organik madde bakımından genelde fakir olduğunu ortaya koymaktadır. Buna bağlı olarak sulamalı tarımla birlikte yöre çiftçileri, üretimi ve verimi artırmak amacıyla yaygın bir şekilde kimyasal gübre kullanımı artacak ve bu aşırı gübre kullanımı sonucunda da ortaya çıkan hastalık ve zararlılarla mücadele etmek için de tarımsal ilaçlar kullanılacaktır. Bu aşırı kimyasal gübre ve tarımsal ilaç kullanımı ile tarımsal toprakların kirlenme riski artacaktır.

Tarımsal faaliyetlerde hastalık ve zararlılarla mücadelede kullanılabilecek iki temel yöntem vardır. Bunlardan birincisi kültürel ve biyolojik mücadele, diğeri ise organik tarımdır. Nitekim yapılan araştırmalar sonucunda, organik tarım yoğun tarım sonucu giderek artan çevre ve sağlık sorunlarının çözümünde etkin bir yöntem olarak kabul edilmektedir. Bu bağlamda, GAP Bölgesi toprakları kirlenmemiş, ekolojik tarım için büyük bir potansiyel arz etmektedir. Ekolojik tarımın çalışma alanımızda gelişebilmesi için kamu ve ilgili kuruluşlarca, yöre çiftçileri bilinçlendirilerek doğru yönlendirilmeli ve gerekli konularda ve özellikle yöntem ve ürün pazarlama kanalları konusunda destek verilmelidir. Aslında ekolojik tarımda iyi bir yöntem ve doğru bir pazarlama ağı kurulursa, yurt içinde en azında bu aşamada talep bulmasa dahi yurtdışında geniş bir müşteri potansiyelinin varlığı nedeniyle önemli talepler gelecektir.

\section{Ulaşım ve Pazarlama}

Üretilen hammaddelerin, sanayi ürünlerinin ve hizmetlerin para kazanmak amaciyla kitlelere ulaştırılarak tanıtılması ve sunulması işine pazarlama; pazarlanan ürünlerin para veya mal karşılığı el değiştirmesine ticaret denilmektedir (Özzçağlar, 2000: 161). Çalışma alanımızdaki üreticiler, tarımsal ürünlerin pazarlanmasında genel olarak iki temel sorunla karşı karşıyadırlar. Bunlardan birincisi; üreticinin örgütlü olmamasından dolayı üretilen tarımsal ürünlerinin piyasada değeri üzerinden satılamamasıdır. Çünkü müşteri konumundaki kesim daha bilinçli ve örgütlüdür. İkincisi ise; üreticileri, her yıl piyasa taleplerine göre üretilecek ürün deseni konusunda doğru yönlendirecek pratikte bir devlet politikası veya danışmanlık hizmeti verecek herhangi bir kurumun olmamasıdır. $\mathrm{Bu}$ da, her ürünün piyasasında yıldan yıla değişen bir arz-talep dengesinin ortaya çıkması ve bu istikrarsız durumdan dolayı tarımsal ürünlerin büyük bir kısmında fiyatlar istikrarlı olmayıp, büyük farklılıklar göstermektedir.

Çalışma alanımızda ve çevresinde, pazarlamanın gelişebilmesi için üretici ve tüketici bir nüfus kitlesi mevcuttur. Ancak, özellikle üretici nüfus kitlesinin modern tarım konusunda eğitilmesi zorunlu bir durumdur. Yine de, bölgede ve dolayısıyla çalışma alanımızda, nicel olarak yeterli miktarda bir üretici ve tüketici nüfus; nitel olarak da şartları halen olgunlaşma aşamasında olan bir nüfus kitlesinde bahsetmek mümkündür. Diğer tarafta, tarımsal üretimde ulaşım ve pazarın ayrı bir önemi vardır. Özellikle üretim ticari amaçlara yönelikse, bu önem daha da artar. Çünkü üretimin hangi türü olursa olsun, ticari amaçlara yönelik olarak geliştirilebilmesi için pazar ilişkilerinin kurulmuş olması şarttır. $\mathrm{Bu}$ da amaca uygun bir yol sistemi ile ulaştırma araçlarıyla sıkı bir bağlılık gösterir (Doğanay, 1985: 46). Çalıșma alanımızda ulaşım ve dolayısıyla pazarlama için büyük önem taşıyan üç önemli projeden bahsetmek mümkündür. Bu projelerden birincisi; 2006 y1lı içerisinde bitirilmesi öngörülen GaziantepŞanlıurfa Otoban Projesi, İkincisi; Bu otoban ile bağlantılı olarak Şanlıurfa şehrinin $33 \mathrm{~km}$. kuzeyindeki GAP Uluslararası Havaalanı Projesi, Üçüncüsü ise; çalışma alanımızın güneyinde bulunan Akçakale Gümrük Kapısı Projesidir. Dikkat edilirse bu üç proje, çalışma alnımızda üretilecek tarımsal ürünlerinin bölgesel, ulusal ve uluslararası pazarlara ulaştırmak için en modern ulaşım hizmeti sunmak amacı taşımaktadır. Ayrıca, söz konusu projelerin tamamlanması durumunda, pazarlamanın temel problemlerinde olan ulaşım boyutu da büyük ölçüde çözülmüş olacaktır.

Çalışma alanımızda üretilen tarımsal ürünler genel olarak 4 şekilde pazarlanmaktadır. Bunları; devletin destekleme yoluyla üreticilerinin bazı ürünlerinin satın alması (TMO), tarım satış kooperatifleri (Çukobirlik gibi), özel sektör (tüccar) ve üreticinin kendisinin pazarlaması olarak 
sıralamak mümkündür. Tarım üreticilerin bilinç düzeyi artıkça, tarımsal ürünlerle ilgili pazarlama kanallarının çeşidi ve kalitesi de artacaktır.

\section{Sonuç}

Şanlıurfa ili, mevcut tarım potansiyeli itibariyle zengin ve elverişli bir durum arz etmektedir. Ancak, modern tarım açısından ele alındığında, bu zengin tarım potansiyelinin yeterli ve bilimsel olarak değerlendirilmemesinin bir sonucu olarak çok ciddi temel yapısal sorunlarının ortaya çıktığı dikkat çekmektedir. $\mathrm{Bu}$ temel sorunlarının başında sulama, sermaye, kredi kullanımı, çiftçi örgütlenmesi, makineleşme, kaliteli tohumluk kullanımı, gübre ve tarımsal ilaç kullanımı, pazarlama ve kalifiye insan gücü konularındaki yetersizlikler ve mülkiyet sorunu gelmektedir.

Şanlıurfa ilinde ve dolayısıyla Güneydoğu Anadolu Bölgesi'nde birinci derecede tarım üzerinde olumsuz etki yapan kuraklık durumunu gidermek ve tarım sektörünün temel yapısal sorunlarını ortadan kaldırmak veya en aza indirebilmek için GAP devreye girmiştir. GAP bünyesinde, 17 yıllık (1989-2005) bir dönemi kapsayan süre zarfinda yürütülen çalışmaların, söz konusu projelerin gerek hedeflenen süre içerisinde tamamlanması gerekse bu yapısal sorunların çözüme kavuşturulması noktasında istenilen düzeye henüz ulaşılamadığı, hatta çok düşük bir seviyede gerçekleştiği görülmektedir. Daha da ötesi, GAP Tarım Master Planı'nda bölgenin tarım ve tarıma dayalı sanayi ile kalkınması öngörülmüş olmasına rağmen, 2005 yılı itibariyle, GAP toplamında tamamlanma oranı \% 52,1 iken, tarım sektörüne yönelik yürütülen projelerin tamamlanma oranı sadece $\% 21,1$ 'dir. $\mathrm{Bu}$ durum, GAP çerçevesinde tarım alanındaki projelerin gerçekleşme oranının düşük olmasından dolayı, çalışma alanımızda ve dolayısıyla GAP bölgesinde tarımın temel sorunlarının giderilerek, tarımın modernleşmesini geciktirmektedir.

Bu çerçeveden hareketle, yöre çiftçilerinin bilgi düzeyi artırılmalıdır. Tarım üreticilerinin bilgi ve eğitim düzeyleri arttıkça, yörede ekonomik ve sosyal yapı hızlı bir kalkınma sürecine girilecektir.

\section{Referanslar}

Aksoy, S. ve Diğerleri, (1986), “Tarımsal Ekonomik Yapı” Tarımsal Kalkınma Sempozyumu Bildiri Kitapçı̆̆ı, s.54. Ankara. Aydemir, M. (1982), Pamuk Islahı, Yetiştirme Tekniği ve Lif Özellikleri, s.260-261, İzmir.

Dinler, Z., (2000), Tarım Ekonomisi, 5. Basım, Ekin Kitabevi, s.9, Bursa.

DİE, (2003), 2001 GTS Tarımsal İşletmeler (Hanehalkı) Anketi Sonuçları, s.4, Ankara.

DİE, (2002), Tarımsal Yap1, s.510, Ankara.

Dizdar, M.Y., (2003), Türkiye'nin Toprak Kaynakları, TMMOB Teknik Yayınları Dizisi No: 2, s.273, Ankara.

Doğanay, H., (1987), Ziraat Coğrafyası, A.Ü. Fen-Edb. Fak. Coğ. Böl. Ders Notlerı No: 23, s.46, Erzurum.

Ferhatoğlu, H, ve Anlağan, M. (1996), GAP Bölgesinde Harran Ovası'nda ve Cırcıp Yağmurlama Sulama Alanında Yetiştirilebilecek Pamuk Çeşitleri-II, s.22, Ankara.

Gündoğdu, K.S. ve Arkadaşları, (2003), “Arazi Toplulaştırmasında Parsel Değer Sayılarının Coğrafi Bilgi Sistemi Kullanılarak Belirlenmesi”, U.Ü. Ziraat Fak. Derg. Sayı: 17, s.137-148, Bursa.

GAP-BKI, (1996), GAP Bölgesinde Tarımsal Mekanizasyon Gereksinimleri Etüdü Projesi, s.3, Ankara.

GAP-BKİ, (1996) GAP Bölgesinde Sulu Koşullarda Bitkilerin Yetiştirme Teknikleri, s.35, Ankara.

GAP-BKİ (2003), 2002 Y111 Faaliyet Raporu, s.13, Ankara.

Gürgen, G. (2002), Güneydoğu Anadolu Bölgesinin İklimi, D.Ü. Ziya Gökalp Eğitim Fak. Yay. No: 12, s.145, Diyarbakır.

İnan, İ.H., (2003), "GAP Bölgesi Tarımsal Kalkınmasında Kooperatifçilik”, III. GAP ve Sanayi Kongresi Bildiriler Kitapçığı (18-19 Ekim 2003), s.171, Diyarbakır.

Karlı, B., (2001), "Kooperatifçilik ve Diğer Örgütlenme Modellerine İlişkin Genel Çerçeve", GAP Bölgesi Kırsal Kalkınmasında Kooperatifçilik ve Diğer Örgütlenme Modelleri (Atölye Çalışması 26-27 Aralık 2001), GAP-BKİTürkiye Kooperatifleri, s.12, Ankara.

Tarım ve Köyişleri Bakanlığı, (2002), Şanlıurfa Tarım Master Planı, s.173, Şanlıurfa.

Tarım Reformu Genel Müdürlügü (2003), Toplulaştırma Teknik Talimatı, s.11, Ankara.

TİGEM (2003), TİGEM'de Üretilen Sertifikalı Tohumluklar, s.1, Ankara.

Tümertekin, E. ve Özgüç, N., (1999), Ekonomik Coğrafay Küreselleşme ve Kalkınma, Çantay Kitabevi, s.202, İstanbul.

Özçağlar, A., (2000), Coğrafyaya Giriş-Sistematik, Kavramlar, Yöntemler, s.124, 161, Ankara.

Özer, S. (1999), Gübre ve Gübreleme, S.1, Şanlıurfa.

Öztürkmen, A.R., (2003), "Şanlıurfa Tarımının Sorunları ve Çözüm Önerileri”, III. GAP ve Sanayi Kongresi Bildiriler Kitapçı̆̆ı (18-19 Ekim 2003), s.158, Diyarbakır.

http://www.gap.gov.tr/Turkish/Frames/fr2.html, son erişim tarihi 09.02.2006. 